\title{
Two new species of Knodus (Characidae: Stevardiinae) from the upper rio Tocantins basin, with evidence of a ontogenetic meristic changes
}

\section{Correspondence: Gabriel de Carvalho Deprá gabrieldepra@gmail.com}

Submitted October 2, 2020

Accepted January 1, 2021

by Paulo Lucinda

Epub 08 March, 2021

\author{
${ }^{\oplus}$ Gabriel de Carvalho Deprá ${ }^{\circ}{ }^{-}$Renata Rúbia Ota ${ }^{1}$, \\ ${ }^{\oplus}$ Oscar Barroso Vitorino Júnior ${ }^{1}$ and ${ }^{\circledR}$ Katiane Mara Ferreira ${ }^{2}$
}

Two new species from the upper rio Tocantins basin are described in Knodus based on the traditional definition of the genus. The new species are distinguished from other congeners by meristic and morphometric characters, such as the number of cusps in the premaxillary and dentary teeth, the number of scale series between dorsal-fin origin and lateral line, the orbital diameter and the body depth. With the two new species, the number of endemic species in the upper rio Tocantins basin upstream of the mouth of the rio Paranã, rises to 53 (89 to the confluence with rio Araguaia). The existence of a meristic character that changes through ontogeny (allomery), viz. the number of scale series between dorsal-fin origin and lateral line, was detected in some species of Knodus through a regression analysis. Additionally, this paper describes an unambiguous, more informative and precise new method for counting vertebrae, which will enhance the efficacy of this trait in species comparisons.

Keywords: Allochromy, Allomery, Endemism, Knodus breviceps, Secondary sexual characters.
Online version ISSN 1982-0224

Print version ISSN 1679-6225

Neotrop. Ichthyol.

vol. 19, no. 1, Maringá 2021
1 Programa de Pós-Graduação em Ecologia de Ambientes Aquáticos Continentais, Universidade Estadual de Maringá Av. Colombo, 5790, 87020-900 Maringá, PR, Brazil. (GCD) gabrieldepra@gmail.com (corresponding author); (RRO) renatarubia.ota@gmail.com; (OBVJ) jr.vitorino@gmail.com.

2 Universidade Federal de Mato Grosso, Instituto de Biociências, Departamento de Biologia e Zoologia. Av. Fernando Corrêa da Costa, 2367, Boa Esperança, 78060-900 Cuiabá, MT, Brazil. kmferreira@gmail.com. 
Duas novas espécies do alto rio Tocantins são descritas em Knodus com base na definição tradicional do gênero. As novas espécies são distinguidas das demais congêneres por caracteres merísticos e morfométricos, tais como o número de cúspides nos dentes do pré-maxilar e do dentário, o número de séries de escamas entre a origem da nadadeira dorsal e a linha lateral, o diâmetro da órbita e a altura do corpo. Com as duas novas espécies, o número de espécies endêmicas na bacia do alto rio Tocantins, acima da barra do rio Paranã, sobe para 53 (89 até a confluência com o rio Araguaia). A existência de um caráter merístico que muda ao longo da ontogenia (alomeria), ou seja, o número de séries de escamas entre a origem da nadadeira dorsal e a linha lateral, foi detectado em algumas espécies de Knodus com uma análise de regressão. Adicionalmente, este artigo descreve um novo método não-ambíguo, mas informativo e mais preciso, para a contagem de vértebras, que aumentará a eficácia deste caráter em comparações entre espécies.

Palavras-chave: Alocromia, Alomeria, Caracteres sexuais secundários, Endemismo, Knodus breviceps.

\section{INTRODUCTION}

Taxonomists have traditionally defined Knodus Eigenmann, 1911 as similar to Bryconamericus Eigenmann, 1907 but with small scales covering the proximal half of each caudal-fin lobe. Characters common to both genera include the two series of teeth in the premaxilla, of which the inner one has four teeth, and the ii,7,i or ii, 8 dorsal-fin rays, which characterise most Stevardiinae; few maxillary teeth, dorsal-fin origin distinctly anterior to anal-fin origin, lateral line usually completely pored, absence of modified scales on caudal fin, among others (e.g., Eigenmann, 1918; Géry, 1977, Lima et al., 2004). Lima et al. (2003) tried to provide a complete list of species fitting such definition, described before the $21^{\text {st }}$ century, whose differences Eigenmann (1918) and Géry (1977) attempted to elucidate by means of identification keys, and the thesis by Ferreira (2007) represents an even deeper effort in this sense. As for the species described posteriorly to posteriorly to the checklist of Lima et al. (2003), each one presents autapomorphic characters that facilitate their recognition (Lima et al., 2004; Ferreira, Lima, 2006; Ferreira, Carvajal, 2007; Zarske, Géry, 2006; Zarske, 2007, 2008; Ferreira, Netto-Ferreira, 2010; Esguícero, Castro, 2014; Menezes, Marinho, 2019; Sousa et al., 2020; Menezes et al., 2020).

The composition of Knodus changed slightly with the study by Thomaz et al. (2015, Additional file 5), who attempted a first comprehensive effort to review the stevardiine classification, by means of a molecular phylogeny. As a result, they transferred to Knodus the two species previously placed in Bryconadenos Weitzman, Menezes, Evers \& Burns, 2005 (synonymising, thus, this genus into Knodus), as well as Bryconamericus alpha Eigenmann, 1914, B. cinarucoense Román-Valencia, Taphorn \& Ruiz-C., 2008 and B. deuterodonoides Eigenmann, 1908. On the other hand, Thomaz et al. (2015) recovered Knodus hypopterus (Fowler, 1943) within Bryconacidnus Myers, 1929 (although they did not examine its type species in the study). Most species traditionally placed in Knodus were not included in the analysis by Thomaz et al. (2015) and were tentatively maintained in the genus. 
However, the results by Thomaz et al. (2015) raised issues regarding the diagnosis of the genus, which we must clarify for the purpose of the present work. A compilation of information from the literature allows us to diagnose Knodus as follows: Knodus, except K. tanaothoros (Weitzman, Menezes, Evers \& Burns, 2005) and K. weitzmani (Menezes, Netto-Ferreira \& Ferreira, 2009), differs from all other genera in Stevardiinae, except Aulixidens Böhlke, 1952, Boehlkea Géry, 1966, Bryconacidnus [particularly B. hypopterus, B. paipayensis (Pearson) and B. pectinatus (Vari \& Siebert)], Ceratobranchia Eigenmann, 1914, Lepidocharax Ferreira, Menezes \& Quagio-Grassioto, 2011 and Markiana Eigenmann, 1903 by having small, unmodified scales extending well beyond the base of middle rays of each caudal-fin lobe, $v s$. absence of such scales or presence of modified scales at least in males. Knodus differs from Aulixidens by having two series of teeth in the premaxilla ( $v$ s. one). From Boehlkea, by having usually 2-4 maxillary teeth [rarely 5 in K. figueiredoi Esguícero \& Castro, 2014 and K. savannensis Géry, 1961, 5-6 in K. geryi Lima, Britski \& Machado, 2004; vs. 5-21, less than 12 only in B. weitzmani Soares, Bertaco, Ito \& Zuanon, 2017, which commonly has 7-10]. From Ceratobranchia, by having outer-row teeth much shorter and narrower than innerseries teeth ( $v s$. longer and approximately as wide). From Lepidocharax, by the anal-fin origin distinctly posterior to the dorsal-fin origin ( $v s$. at the same vertical or slightly posterior to it). From Markiana, by having less than 30 branched rays on anal fin (vs. 38-46). Knodus tanaothoros and K. weitzmani differ from other species in Stevardiinae by the shape of the anal-fin organ, as described by Weitzman et al. (2005) and Menezes et al. (2009).

There is no clear diagnosis between Knodus and Bryconacidnus or Bryconamericus. According to the definition of Eigenmann (1918), Knodus differs from both Bryconacidnus and Bryconamericus by the caudal-fin scaling. The extent of scales onto caudal-fin rays has been oversimplified into a binary character (caudal fin "scaled" or not), causing ambiguous interpretations of various authors, which resulted in conflicting opinions concerning the allocation of the species (Menezes et al., 2020). For example, the original description of Bryconamericus beta Eigenmann, 1914 (synonym of K. alpha (Eigenmann, 1914)) and $K$. deuterodonoides points to the presence of scales covering the caudal fin lobes, and yet these species were described as Bryconamericus. One of the authors (KMF) examined the type material of these species and confirms that both species present scales covering the caudal-fin lobes. Knodus cinarucoense was described in Bryconamericus in accordance with the explicit mention of a caudal fin not scaled (Román-Valencia et al., 2008). However, analysing topotypes of $K$. cinarucoense, we observed the presence of scales covering the lobes of the caudal fin. Although there is still no consensus on how to delimit Knodus and Bryconamericus using the extension of the scales that cover the caudal-fin lobes, molecular studies point to the validity of both genera (see Thomaz et al., 2015; Mirande, 2019; García-Melo et al., 2019).

In the absence of an accurate diagnosis of Knodus and Bryconamericus, a solution is to allocate new species in either of these genera according to the traditional definitions by Eigenmann $(1918,1927)$ and Eigenmann, Myers (1929). Thus, presently Knodus includes 30 species: K. alpha, K. angustus Menezes, Ferreira \& Netto-Ferreira, 2020, K. borki Zarske, 2008, K. breviceps (Eigenmann, 1908), K. chapadae (Fowler, 1906), K. cinarucoense, K. cupariensis Sousa, Silva-Oliveira, Canto \& Ribeiro, 2020, K. delta Géry, 1972, K. deuterodonoides, K. dorsomaculatus Ferreira \& Netto-Ferreira, 2010, K. 
figueiredoi, K. gamma Géry, 1972, K. geryi, K. heteresthes (Eigenmann, 1908), K. longus (Zarske \& Géry, 2006), K. megalops (Myers, 1929), K. meridae Eigenmann, 1911 (typespecies), K. mizquae (Fowler, 1943), K. moenkhausii (Eigenmann \& Kennedy, 1903), K. nuptialis Menezes \& Marinho, 2019, K. orteguasae (Fowler, 1943), K. pasco Zarske, 2007, K. savannensis, K. septentrionalis Géry, 1972, K. shinahota Ferreira \& Carvajal, 2007, K. smithi (Fowler, 1913), K. tanaothoros, K. tiquiensis Ferreira \& Lima, 2006, K. victoriae (Steindachner, 1907) and K. weitzmani.

Recent collections in the upper rio Tocantins basin yielded two new species that fit the traditional definition of Knodus. One of them shares uniquely with Knodus figueiredoi the presence of up to three cusps on the jaw teeth. The other one is more generalised in body shape and lacks unique characters. We provide a formal description for both species.

\section{MATERIAL AND METHODS}

Counts and measurements followed the methodology presented by Fink, Weitzman (1974), except when noted otherwise. Measurements were taken on the left side of the specimens whenever possible, using a digital calliper to the nearest $0.1 \mathrm{~mm}$. Clearing and staining of specimens followed Taylor, Van Dyke (1985), and was employed for counting vertebrae, ribs, supraneurals, pterygiophores, epurals, uroneurals, procurrent rays and external and internal rakers of all branchial arches, as well as for describing osteological differences between the species described herein.

Vertebrae were counted as follows. The Weberian apparatus represents four abdominal vertebrae, which are those whose transverse process (= haemapophysis) touches the peritoneum (no abdominal vertebrae with a complete haemal spine or with a hypapophysis were found in specimens analysed herein). Caudal vertebrae are those whose transverse process does not touch the peritoneum (the anteriormost caudal vertebra touches the peritoneum anteriorly by the haemal spine; in the specimens analysed herein, the caudal vertebrae always have a haemal spine). The fused preural and first ural centra $(\mathrm{PU} 1+\mathrm{U} 1)$ of the caudal region was counted as a single element. The vertebrae between the Weberian apparatus and the PU1+U1, whether abdominal or caudal, were classified in one of the following types (Fig. 1). Type A: typical abdominal vertebra, with short transverse process bearing a well-developed rib. Type B: transverse process long, ventrally directed, lacking the rib or bearing a vestigial one, and united with the contralateral process by a bony bridge proximal to the tip, delimiting a pseudohaemal canal (Mirande, 2010, character 229, described such bony bridge, which would be diagnostic of his 'transitional vertebrae'; according to him, our type $\mathrm{C}$ would also be of the transitional kind). Type C: similar to type B, but with a haemal spine, which barely touches the tip of the transverse process (= haemapophysis), so that two canals are formed between the contralateral transverse processes (i.e., a pseudo-haemal canal contained in a true haemal canal). Type D: typical caudal vertebra, with a haemal spine and a haemal canal, but no pseudo-haemal canal. This method of classification of vertebrae is unambiguous and more informative than the usual distinction between abdominal and caudal vertebrae, and can be expanded indefinitely as other vertebral types are described. 


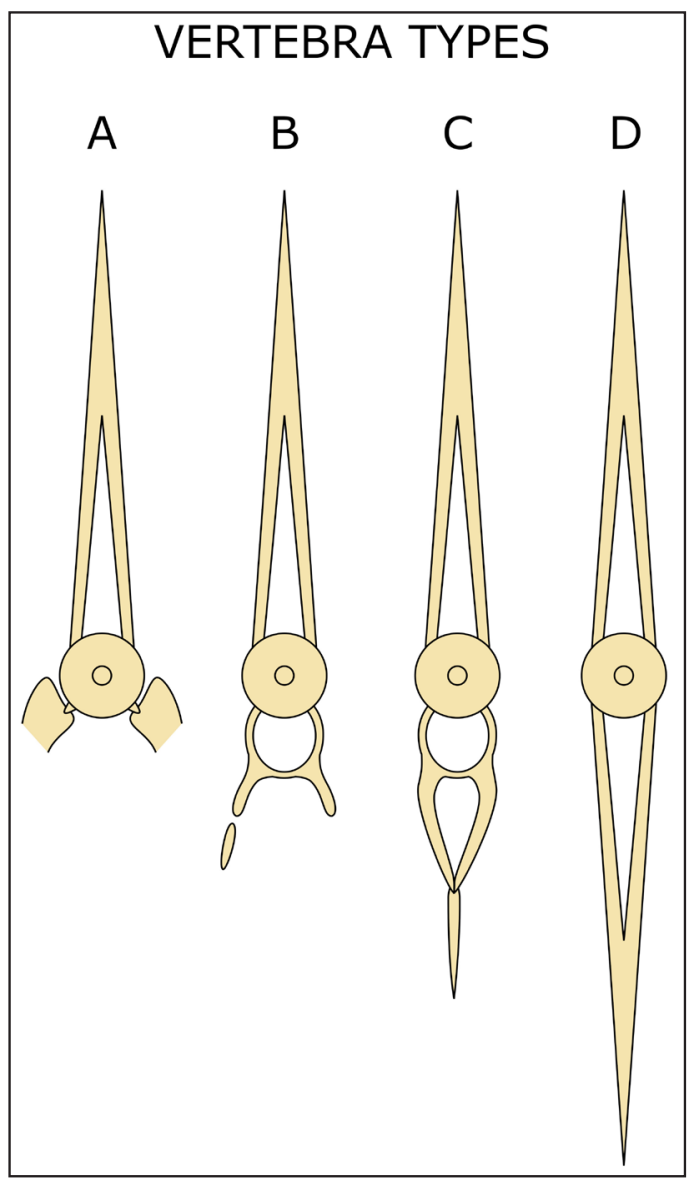

FIGURE 1 I Schematic representation of four types of vertebra. In A., only the proximal portion of the ribs is shown. In B., the small bony fragment close to the tip of the transverse process in the left is an underdeveloped rib shown in full. In $\mathbf{C}$., the haemal spine is not fused to the tip of the contralateral transverse processes, which meet each other medially. Notice that in $\mathbf{D}$. the fusion is complete, but the bony ring, present in $\mathbf{B}$. and $\mathbf{C}$., is absent.

We examined the following species for variation in the number of scales between dorsal-fin origin and lateral line, other than the two new species described herein: $K$. aff. breviceps, K. chapadae, K. moenkhausii, K. victoriae, K. sp. A, K. sp. B, K. sp. C, K. sp. D, K. sp. E, K. sp. F, K. sp. G and K. sp. H. Knodus aff. breviceps (= Knodus chapadae of Ferreira, 2007 , in part) refers to a long-snouted species that is syntopic with the two new species described herein, but differs from the type series of $K$. breviceps in having a longer head. Knodus sp. A-H refer to putatively undescribed species and selected lots of each of these species are listed under 'Comparative material examined'.

Herein we introduce two new terms related to ontogenetic processes. Both have been used before, but in very different contexts, such as other biological areas, physics, chemistry and mineralogy, and will not cause any ambiguity. The term allomery (from the Greek, á $\lambda \lambda$ os, other, $\mu$ f́pos, component; not to be confused with the homonymous term allomery, meaning an abnormal variation in meristic traits in, e.g., domestic plants), means an ontogenetic meristic change, i.e., a shift in the 
number of serially homologous parts, such as scales, fin rays and gill rakers, during growth. That phenomenon has been reported previously, although not with the same name, by e.g., Hildebrand, Schroeder (1928, p. 93) in Alosa sapidissima (Wilson) (Clupeidae), Berry, Barrett (1963) in Opisthonema Gill (Clupeidae) and Chen (1971, table 16) in Sebastomus Gill (= Sebastes Cuvier; Sebastidae). The term allochromy (from the Greek, $\alpha \lambda \lambda$ os, other, $\chi \rho \omega ́ \mu \alpha$, colour) means an ontogenetic colour-pattern change, either a conspicuous one (such as the black coloration developed by adults of Serrasalmus rhombeus Linnaeus, for instance) or a mild one. Not to be confused with sexual dichromatism, which means a colour-pattern difference between individuals of different genders. The new terms are complementary to allometry, i.e., the ontogenetic change in continuous characters.

In the list of examined material, total specimen counts are followed by the number of specimens analysed (whenever those numbers differ), and by those cleared and stained (c\&s), if any. In the descriptions, the asterisk indicates the count of the holotype. Diagnostic characters of species not examined herein were gathered in the original descriptions, cited in the Introduction. Institutional abbreviations followed Sabaj (2020). Specimens fixed in 90\% ethanol are intended to be used in molecular analyses, thus some morphological traits may be damaged, making the specimens unsuitable for being types.

\section{RESULTS}

\section{Knodus rufford, new species}

urn:lsid:zoobank.org:act:BC88B912-CF9A-47EA-ABFF-746043DCD06F

(Figs. 2-5; Tabs. 1-2)

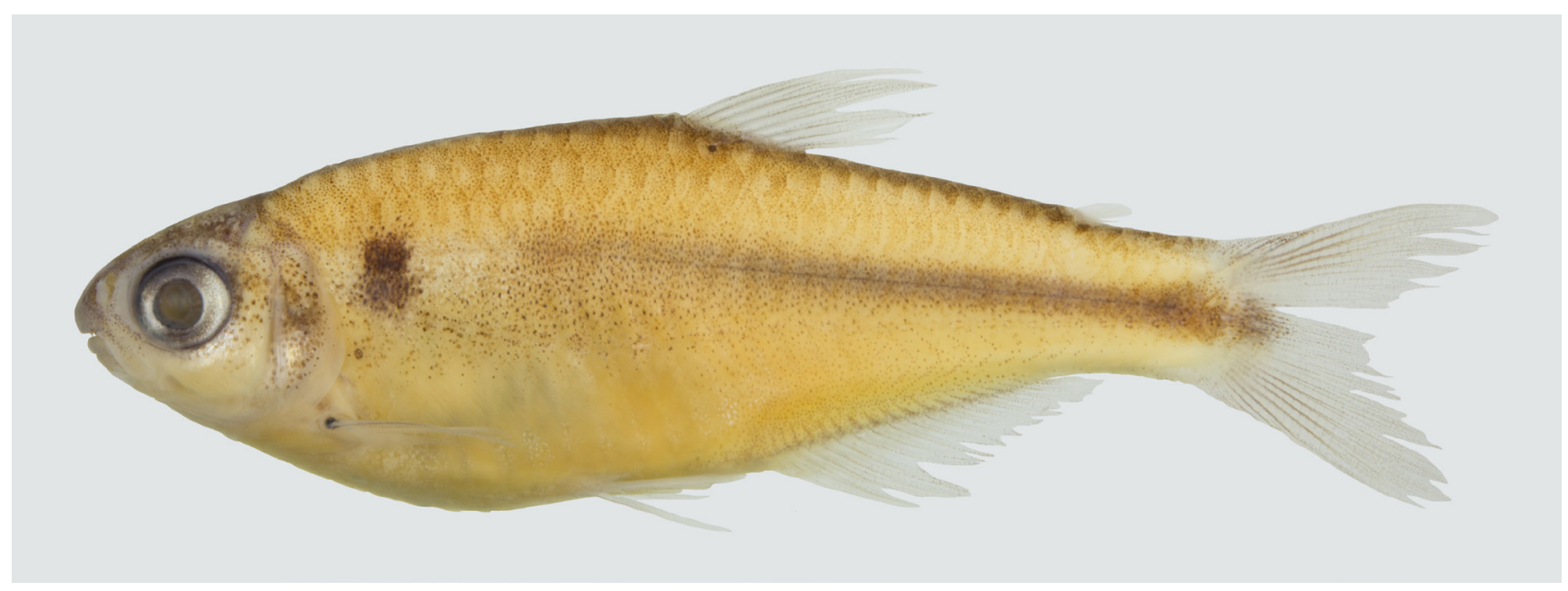

FIGURE 2 I Knodus rufford, holotype, NUP 22661, 35.4 mm SL, ribeirão Dois Irmãos, tributary to the rio do Peixe, tributary to the rio das Almas, tributary to the rio Maranhão, tributary to the rio Tocantins, Municipality of Pirenópolis, Goiás State, Brazil. 


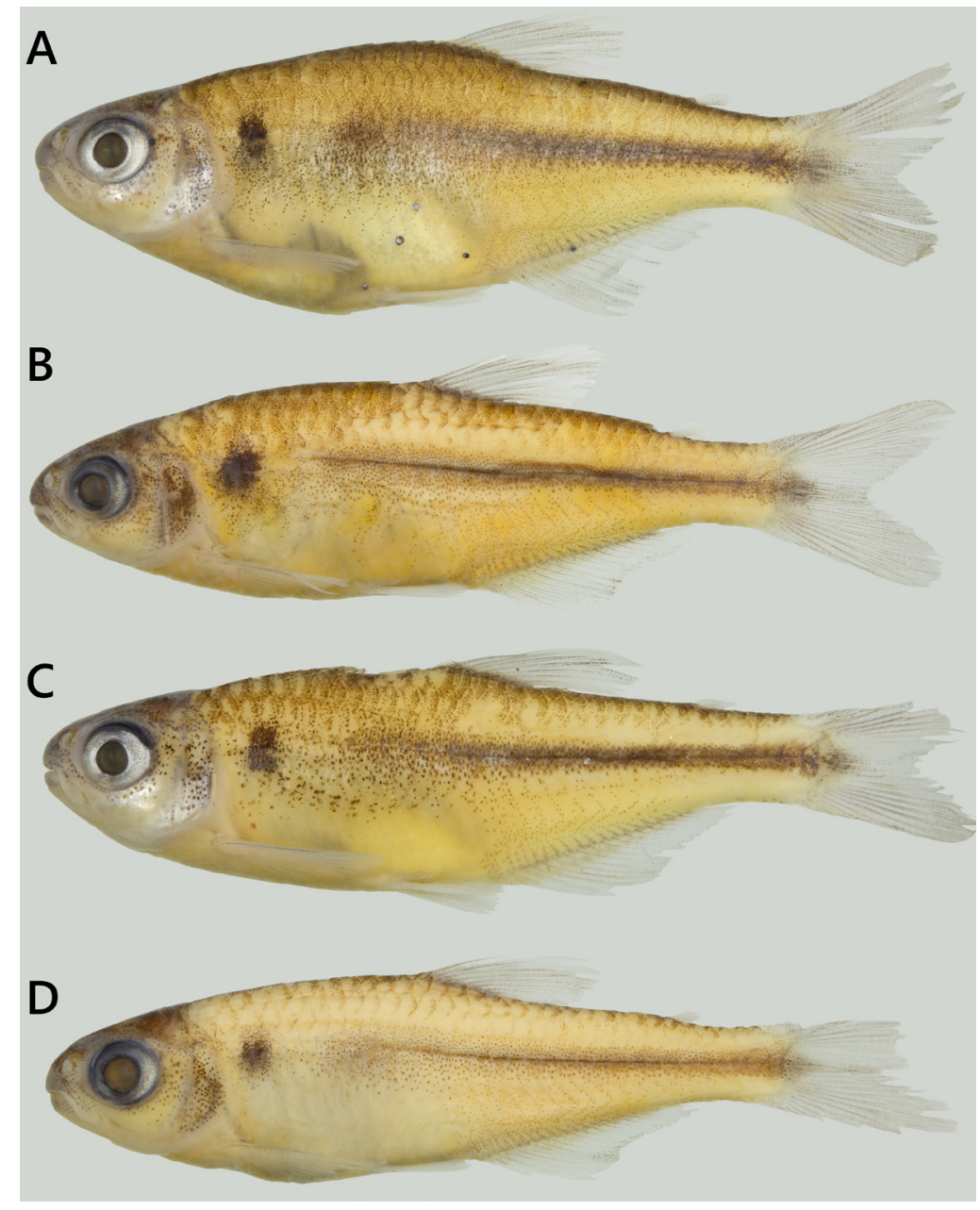

FIGURE 3 । Knodus rufford, paratypes. Ontogenetic and polymorphic variation of the body shape and colour patterns. All from the ribeirão Dois Irmãos drainage, upper Tocantins basin in Pirenópolis, Goiás State, Brazil. A. NUP 22669, 39.2 mm SL. B. CPUFMT 6835, 31.7 mm SL. C. NUP 22669, 28.1 mm SL. D. CPUFMT 6835, $25.2 \mathrm{~mm}$ SL.

Holotype. NUP 22661, 35.4 mm SL, Brazil, Goiás State, Municipality of Pirenópolis, ribeirão Dois Irmãos, tributary to the rio do Peixe, tributary to the rio das Almas, tributary to the rio Maranhão, tributary to the rio Tocantins, $15^{\circ} 42^{\prime} 50^{\prime \prime} \mathrm{S} 49^{\circ} 2^{\prime} 39^{\prime \prime} \mathrm{W}$, elevation 713 m, 12 Dec 2016, G. C. Deprá \& O. Vitorino Júnior.

Paratypes. All from Brazil, State of Goiás, Goiás State, Municipality of Pirenópolis, ribeirão Dois Irmãos, tributary to the rio do Peixe, tributary to the rio das Almas, tributary to the rio Maranhão, tributary to the rio Tocantins. CPUFMT 6834, 1 c\&s, $33.1 \mathrm{~mm} \mathrm{SL}$, collected with holotype. CPUFMT 6835, 2, 25.2-31.7 mm SL, 1542’57’S 4952’37’W, elevation 715 m, 12 Dec 2016, G. C. Deprá \& O. Vitorino Júnior. MCP 54464, 1, $31.8 \mathrm{~mm}$ SL, 1542’50”S 49²’54”W, elevation $702 \mathrm{~m}, 12$ Dec 2016, G. C. Deprá \& O. Vitorino Júnior. NUP 22660, 28.2-36.8, collected with holotype. NUP 22669, 4, 28.1-39.2 mm SL, type locality, 24 Apr 2017, G. C. Deprá \& O. Vitorino Júnior. 
Non-type. CPUFMT 6833, 1 (fixed in 90\% ethanol), $34.4 \mathrm{~mm} \mathrm{SL}$, Brazil, Goiás State, Municipality of Pirenópolis, ribeirão das Araras, tributary to the ribeirão Dois Irmãos, tributary to the rio do Peixe, tributary to the rio das Almas, tributary to the rio Maranhão, tributary to the rio Tocantins, $15^{\circ} 42^{\prime} 15^{\prime} \mathrm{S} 49^{\circ} 2^{\prime} 12^{\prime} \mathrm{W}$, elevation $722 \mathrm{~m}, 12$ Dec 2016, G. C. Deprá \& O. Vitorino Júnior.

Diagnosis. Knodus rufford differs from all other congeners bearing caudal-fin scales, except K. figueiredoi, and from Bryconacidnus hypopterus, by having up to three cusps in the premaxillary inner row teeth and dentary teeth (rarely a fourth or fifth cusp present in one or two premaxillary teeth). Knodus rufford differs from K. figueiredoi by having $4-4 \frac{1}{2}$ scales between dorsal-fin origin and lateral line ( $\left.v s .5\right), 11-12$ circumpeduncular scale rows (vs. 13-14), and i,6,i pelvic-fin rays (two specimens with i,5,i; vs. always $\mathrm{i}, 5, \mathrm{i})$. Additionally, the number of scale rows between dorsal-fin origin and lateral line distinguishes Knodus rufford from all congeners bearing caudal-fin scales, except $K$. cupariensis, K. meridae, K. nuptialis, K. orteguasae and smaller specimens of the syntopic $K$. aff. breviceps and $K$. obolus (new species, described below), and from Bryconacidnus hypopterus. The number of circumpeduncular scale rows distinguishes $K$. rufford from all congeners bearing caudal-fin scales, except K. angustus, K. borki, K. cupariensis, K. delta, K. longus, K. nuptialis, and K. pasco, and from B. hypopterus. The completely pored lateral line distinguishes $K$. rufford from $K$. borki (incomplete, 6-14 perforated scales) and $K$. delta (8-12). The absence of distinct marks from all fins distinguishes $K$. rufford from $K$. dorsomaculatus (a black band present on proximal third of dorsal fin), K. cupariensis and K. geryi (a black spot on the base of each caudal-fin lobe), K. pasco (a horizontal black band present on the middle of dorsal fin) and K. savannensis (a distinct black band running along middle caudal fin rays and extending through distal half of ventral caudal-fin lobe). The body depth (28.6-34.7\% SL) distinguishes $K$. rufford from $K$. angustus (20.0-25.2), K. longus (22.5-23.7), K. megalops (34.2-41.6) and K. obolus (36.640.1). The presence of 1-4 maxillary teeth distinguishes $K$. rufford from K. pasco (5-6). The presence of $2 \frac{1}{2}-3$ scales between lateral line and pelvic-fin origin distinguishes $K$. rufford from K. chapadae (31/2-4) and K. shinahota (5). The presence of normally developed skin folds on the base of the first few branched anal-fin rays ( $v$ s. highly developed) and the absence of a second humeral blotch (vs. presence) distinguishes $K$. rufford from $K$. tiquiensis. The absence of breeding tubercles distinguishes $K$. rufford from K. nuptialis. Other characters, although shared with several other congeners, help distinguishing Knodus rufford. The number of branched anal-fin rays (15-17) distinguishes K. rufford from all congeners bearing caudal-fin scales, except $K$. angustus, K. breviceps, K. chapadae, K. figueiredoi, K. geryi, K. heteresthes, K. longus, K. meridae (more frequently 13 or 14), K. mizquae, K. orteguasae, and K. tiquiensis, and from B. hypopterus. The number of scales in the longitudinal series (34-36, all of which are perforated in $K$. rufford) distinguishes $K$. rufford from all congeners bearing caudal-fin scales, except $K$. borki (lateral line incomplete), K. cupariensis, $K$. delta (lateral line incomplete), K. figueiredoi, K. gamma, $K$. heteresthes, K. megalops, K. meridae, K. nuptialis, K. orteguasae, K. savannensis, K. shinahota and $K$. victoriae.

Description. Morphometric data in Tab. 1. Body compressed, greatest body depth anterior to vertical through dorsal-fin origin. Dorsal profile of body convex 
from upper lip to vertical through nostril; slightly convex from this point to base of supraoccipital bone; slightly concave from this point to distal tip of supraoccipital process. Ascending, slightly convex from tip of supraoccipital process to dorsal-fin origin; descending, straight along dorsal-fin base; continuing almost straight to adipose-fin origin and along caudal peduncle. Ventral profile of body convex from lower lip to anal-fin origin; straight along anal-fin base; and concave to almost straight along caudal peduncle.

Jaws slightly retrognathous, mouth terminal. Premaxillary teeth in two rows. Outer row with $3(3), 4^{\star}(6)$, or $5(2)$ conical to tricuspid teeth. Inner row with $4^{\star}(11)$ teeth, all of them tricuspid in eight specimens; in the holotype, the third tooth (from symphysis) is pentacuspid; in one specimen $(28.8 \mathrm{~mm} \mathrm{SL})$, the symphyseal tooth is tetracuspid; and in one specimen $(28.2 \mathrm{~mm} \mathrm{SL})$, the second and the third teeth are tetracuspid. Posterior margin of maxilla posterior to vertical through anterior margin of orbit. Maxilla with $1(1), 2(2), 3^{\star}(7)$, or $4(1)$ tricuspid teeth. Dentary with $3(1)$, or $4^{\star}(10)$ tricuspid teeth, gradually decreasing in size, followed by up to seven conical and abruptly smaller teeth. Central cusp longer than lateral ones.

Scales cycloid, with few radii (3-5); circuli markedly anterior and marginally (dorsally and ventrally). Lateral line completely pored with $34(1), 35^{\star}(7)$, or $36(2)$ perforated scales. Scale rows between dorsal-fin origin and lateral line $4(6)$, or $4 \frac{1}{2^{*}}(4)$. Scale rows between lateral line and pelvic-fin insertion $2 \frac{1}{2}(8)$, or $3^{\star}(3)$. Predorsal series with irregular pattern, uniserial with $9(1), 10(2)$ scales, or bisserial on anterior portion and uniserial on posterior portion, $6^{\star}(4), 7(3), 8(1), 10(3)$ scales in midline. Single row of up to 15 scales covering base of anal-fin rays. Circumpeduncular scales $11^{\star}(4)$ or $12(4)$. A single series of 13(2), 14(1) scales covering the entire anal-fin base.

Dorsal-fin rays ii,6,ii (1; penultimate element in process of bifurcation) or ii, $7, \mathrm{i}^{\star}(10)$. Adipose fin present. Pectoral-fin rays i,9,i(2), i,9,ii(1), or i,10, $\mathrm{i}^{\star}(8)$, distal tip of rays not reaching pelvic-fin origin. Pelvic-fin rays i, $6(1)$, or i, $6, \mathrm{i}^{\star}(10)$, distal tip reaching anal-fin origin. Anal-fin rays iii,15(3), iii,16 $(7)$, or iii,17(1), as seen in entire specimens (but see Tab. 2 for c\&s specimen). Caudal fin bifurcate, lobes approximately of same size, i,9/8,i rays.

First gill arch with 4(2), or $5^{\star}(9)$ external rakers on upper limb, 1(11) on intermediate cartilage, and $8(8), 9(2)$, or $10^{\star}(1)$ on lower limb, as can be seen in entire specimens. For a more detailed gill-raker count of the c\&s specimen, see Tab. 2. Branchiostegal rays $4(11)$.

Osteology. General appearance of c\&s specimen shown in Fig. 4. Meristic osteological characters are summarised in Tab. 2. Rhinosphenoid ossified (Fig. 4); epiphyseal branch of the laterosensory canal present. Contralateral frontals contacting along about $90 \%$ of distance between mesethmoid and epiphyseal bar, with left frontal bearing expansion over right one. Anterior fontanelle length less than 10\% posterior fontanelle length. Posteromedial corner of parietal rounded. Parasphenoid bar slightly arched. Anteroventral process of mesethmoid well developed, nested between contralateral premaxillae. Pharyngobranchial 2 toothless, much shorter than pharyngobranchial 3. Ossifications dorsal to cartilage between basibranchials 2-3 absent. Ceratohyal with deep notch at the articulation with branchiostegal rays 2-3. 
TABLE 1 I Morphometric data of Knodus rufford. SD = standard deviation; $\mathrm{N}$ = number of specimens.

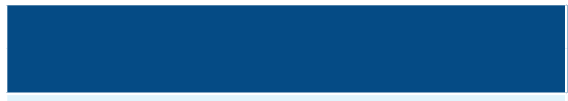

\section{Percentages of standard length} Body depth Predorsal distance Prepectoral distance Prepelvic distance Preanal distance Caudal-peduncle depth Caudal-peduncle length Dorsal-fin base length Dorsal-fin length Pectoral-fin length Pelvic-fin length Anal-fin base length Anal-fin length Orbit to dorsal-fin origin Dorsal-fin origin to caudal peduncle Head depth Head length Percentages of head length Orbital diameter Snout length Interorbital width Upper-jaw length

\section{Holotype}

36.8
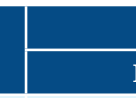

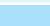

10

N

10

\begin{tabular}{|l|l|}
\hline 34.2 & 10 \\
\hline 54.9 & 10 \\
\hline 23.9 & 10 \\
\hline 46.7 & 10 \\
\hline 63.3 & 10 \\
\hline
\end{tabular}

63.3

12.0

13.6

11.7

24.5

21.5

15.2

26.6

17.9

42.1

50.0

25.0

24.7

37.4

28.6

37.4

37.4

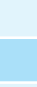

10

10

10

10

10

10

10

10

10

10

10

10

10

10

10

10

10

10

10

10

\begin{tabular}{l}
10 \\
10 \\
10 \\
10 \\
\hline
\end{tabular}

\begin{tabular}{|l|}
\hline $24.8-26.8$ \\
\hline $36.2-39.8$ \\
\hline $24.2-26.7$ \\
\hline $34.1-39.0$ \\
\hline $36.2-38.4$ \\
\hline
\end{tabular}

25.2-39.2

\section{Paratypes}

\begin{tabular}{l|l|l} 
Range & Mean & SD
\end{tabular}

31.4

\begin{tabular}{l|l}
31.6 & 2.2
\end{tabular}

\begin{tabular}{l|l}
54.3 & 1.3
\end{tabular}

\begin{tabular}{l|l}
25.1 & 0.7
\end{tabular}

\begin{tabular}{l|l}
$47.9+1.0$ \\
\hline
\end{tabular}

\begin{tabular}{l|l}
62.3 & 1.3
\end{tabular}

$\begin{array}{ll}11.4 & 1.0\end{array}$

$\begin{array}{ll}13.4 & 0.5\end{array}$

\begin{tabular}{l|l}
12.2 & 0.8
\end{tabular}

\begin{tabular}{l|l}
24.4 & 1.3
\end{tabular}

\begin{tabular}{l}
$21.9+0.5$ \\
\hline 15.1
\end{tabular}

$\begin{array}{ll}15.1 & 0.7\end{array}$

\begin{tabular}{l|l|}
26.6 & 1.4
\end{tabular}

\begin{tabular}{l|l}
17.3 & 1.0 \\
\hline
\end{tabular}

\begin{tabular}{l|l|}
41.6 & 1.4
\end{tabular}

\begin{tabular}{l|l}
49.4 & 1.8 \\
\hline
\end{tabular}

\begin{tabular}{l|l}
24.6 & 0.6
\end{tabular}

\begin{tabular}{l|l}
25.6 & 0.7
\end{tabular}

\begin{tabular}{|l|l|}
\hline 38.2 & 1.2 \\
\hline 26.0 & 0.7 \\
\hline 37.3 & 1.4 \\
\hline 37.4 & 0.6 \\
\hline
\end{tabular}

TABLE 2 I Meristic osteological characters of Knodus rufford (CPUFMT 6834) and K. obolus (CPUFMT 6837). Numbers in parenthesis after a tooth count represent the number of cusps, from medial to lateral. Counts of gill rakers given as follows: total value (rakers attached to pharyngobranchial; between pharyngobranchial and epibranchial; on epibranchial; between epibranchial and ceratobranchial; on ceratobranchial; between ceratobranchial and hypobranchial; on hypobranchial).

\begin{tabular}{|c|c|c|c|}
\hline & \multirow{2}{*}{$\begin{array}{c}\text { K. rufford } \\
\text { paratype }\end{array}$} & \multicolumn{2}{|c|}{ K. obolus } \\
\hline & & paratype 1 & paratype 2 \\
\hline \multicolumn{4}{|l|}{ Teeth } \\
\hline \multicolumn{4}{|l|}{ Pre-maxilla } \\
\hline Outer series & $\begin{array}{c}4(3,3,3,3) ; 1^{\text {st }} \text { and } 4^{\text {th }} \text { turned } \\
\text { outwards }\end{array}$ & $\begin{array}{l}5(3,3,3,3,3) ; 1^{\text {st }}, 3^{\text {rd }} \text { and } 5^{\text {th }} \\
\text { slightly turned outwards }\end{array}$ & $\begin{array}{c}4(3,3,3,3) ; 1^{\text {st }} \text { and } 4^{\text {th }} \text { slightly } \\
\text { turned outwards }\end{array}$ \\
\hline Inner series & $4(3,3,5,4)$ & $4(4,5,5,5)$ & $4(5,7,7,6)$ \\
\hline Maxilla & $3(3,3,3)$ & $2(5,5)$ & $3(5,5,4)$ \\
\hline Dentary & $\begin{array}{l}3 \text { large }(3,3,3), 1 \text { intermediate } \\
\text { (3), } 5 \text { small }(1,1,1,1,1 \text {; the first } \\
\text { with minute lateral cusps) }\end{array}$ & $\begin{array}{l}3 \text { large }(5,5,5), 1 \text { intermediate } \\
\quad(5), 4 \text { small }(4,3,3,3)\end{array}$ & $\begin{array}{c}3 \text { large (all pentacuspid), } 1 \\
\text { intermediate }(5), 5 \text { small }(5,3, \\
3,3,2)\end{array}$ \\
\hline \multicolumn{4}{|l|}{ Vertebrae } \\
\hline Total & 35 & 34 & 35 \\
\hline Abdominal & 16 & 16 & 16 \\
\hline
\end{tabular}


TABLE 2 I (Continued)

\begin{tabular}{|c|c|c|c|}
\hline & \multirow{2}{*}{$\frac{\text { K. rufford }}{\text { paratype }}$} & \multicolumn{2}{|c|}{ K. obolus } \\
\hline & & paratype 1 & paratype 2 \\
\hline Weberian apparatus & 4 & 4 & 4 \\
\hline Type A & 11 & 11 & 11 \\
\hline Type B & 1 & 1 & 1 \\
\hline Caudal & 19 & 18 & 19 \\
\hline Type C & 1 (Fig. 4) & 0 & 0 \\
\hline Type D & 17 & 17 & 18 \\
\hline $\mathrm{PU} 1+\mathrm{U} 1$ & 1 & 1 & 1 \\
\hline \multicolumn{4}{|l|}{ Ribs } \\
\hline Total & 11 & 11 & 11 \\
\hline Vertebrae bearing ribs & $5^{\text {th }}-15^{\text {th }}$ & $5^{\text {th }}-15^{\text {th }}$ & $5^{\text {th }}-15^{\text {th }}$ \\
\hline \multicolumn{4}{|l|}{ Supraneurals } \\
\hline Total & 5 & 5 & 5 \\
\hline Globular & 1 (Fig. 4) & 0 & 0 \\
\hline Rod-like & 4 & 5 & 4 \\
\hline Bifid & 0 & 0 & 1 (Fig. 8) \\
\hline Vertebrae surrounding supraneurals & $4^{\text {th }-9^{\text {th }}}$ & $4^{\text {th }-9^{\text {th }}}$ & $4^{\text {th }-9^{\text {th }}}$ \\
\hline Dorsal-fin proximal pterygiophores & 9 & 9 & 9 \\
\hline $\begin{array}{r}\text { Vertebrae surrounding dorsal-fin proximal } \\
\text { pterygiophores }\end{array}$ & $11^{\text {th }}-17^{\text {th }}$ & $10^{\text {th }}-17^{\text {th }}$ & $10^{\text {th }}-17^{\text {th }}$ \\
\hline Anal-fin proximal pterygiophores & 17 & 19 & 17 \\
\hline $\begin{array}{l}\text { Vertebrae surrounding anal-fin proximal } \\
\text { pterygiophores (asterisk indicates that the } \\
\text { anteriormost pterygiophore touches the } \\
\text { anterior margin of the haemal spine) }\end{array}$ & $17^{\text {th }}-26^{\text {th }}$ & $17^{\text {th* }}-26^{\text {th }}$ & $17^{\text {th } *}-26^{\text {th }}$ \\
\hline Epurals & 3 (two of them partly fused) & 2 & 2 \\
\hline Uroneurals & 1 & 1 & 1 \\
\hline Branchiostegal rays & 4 & 4 & 4 \\
\hline \multicolumn{4}{|l|}{ Gill rakers } \\
\hline \multicolumn{4}{|l|}{ First arch } \\
\hline External & $14(0 ; 1 ; 4 ; 0 ; 6 ; 1 ; 2)$ & $16(0 ; 1 ; 5 ; 1 ; 6 ; 0 ; 3)$ & $20(0 ; 1 ; 6 ; 1 ; 8 ; 1 ; 3)$ \\
\hline Internal & $5(0 ; 0 ; 4 ; 0 ; 1$ minute; $0 ; 0)$ & $5(0 ; 0 ; 5 ; 0 ; 0 ; 0 ; 0)$ & $5(0 ; 0 ; 5 ; 0 ; 0 ; 0 ; 0)$ \\
\hline \multicolumn{4}{|l|}{ Second arch } \\
\hline External & $14(1 ; 0 ; 4 ; 1 ; 6 ; 0 ; 2)$ & $16(1 ; 0 ; 5 ; 1 ; 6 ; 0 ; 3)$ & $16(0 ; 1 ; 5 ; 1 ; 6 ; 0 ; 3)$ \\
\hline Internal & $10(0 ; 0 ; 5 ; 0 ; 5 ; 0 ; 0)$ & $11(0 ; 0: 6 ; 0 ; 5 ; 0 ; 0)$ & $\begin{array}{c}12 \text { ( } 0 ; 0 ; 6 \text {, one minute; } 0 ; 6 \text {, one } \\
\text { minute; } 0 ; 0)\end{array}$ \\
\hline \multicolumn{4}{|l|}{ Third arch } \\
\hline External & $13(1 ; 0 ; 4 ; 1 ; 6 ; 1 ; 0)$ & $15(1 ; 0 ; 5 ; 1 ; 6 ; 1 ; 1)$ & $16(2 ; 0 ; 5 ; 1 ; 6 ; 1 ; 1)$ \\
\hline Internal & $9(0 ; 0 ; 4 ; 0 ; 5 ; 0 ; 0)$ & $10(0 ; 0 ; 4 ; 0 ; 6 ; 0 ; 0)$ & $11(0 ; 0 ; 4 ; 0 ; 7 ; 0 ; 0)$ \\
\hline \multicolumn{4}{|l|}{ Fourth arch } \\
\hline External & $9(0 ; 0 ; 2 ; 0 ; 7 ; 0 ; 0)$ & $13(1 ; 0 ; 4 ; 1 ; 7 ; 0 ; 0)$ & $12(0 ; 0 ; 5 ; 0 ; 7 ; 0 ; 0)$ \\
\hline Internal & $7(0 ; 0 ; 1 ; 0 ; 6 ; 0 ; 0)$ & $9(0 ; 0 ; 0 ; 2 ; 7 ; 0 ; 0)$ & $10(0 ; 0 ; 2 ; 1 ; 7 ; 0 ; 0)$ \\
\hline Fifth arch (only external) & $7(0 ; 0 ; 0 ; 0 ; 7 ; 0 ; 0)$ & $8(0 ; 0 ; 0 ; 1 ; 7 ; 0 ; 0)$ & $9(0 ; 0 ; 0 ; 1 ; 8 ; 0 ; 0)$ \\
\hline \multicolumn{4}{|l|}{ Procurrent rays } \\
\hline Caudal fin & 14 & 13 & 12 \\
\hline Anal fin & 4 & 6 & 5 \\
\hline
\end{tabular}




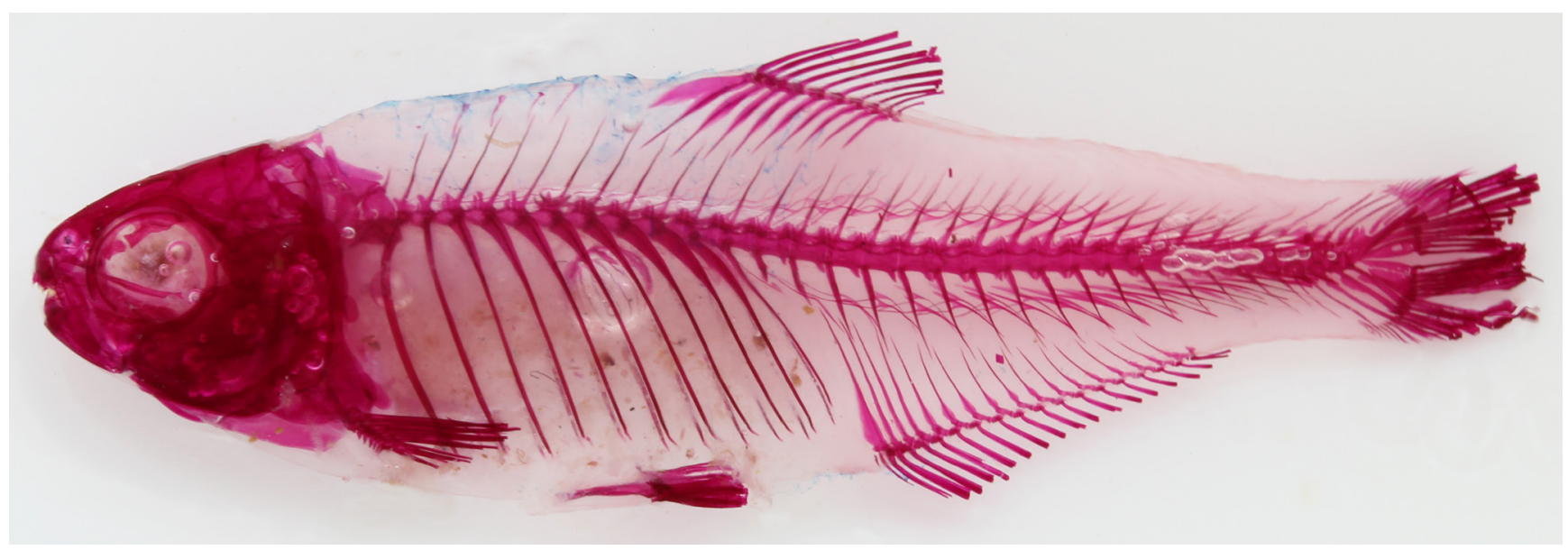

FIGURE 4 I Knodus rufford, c\&s paratype, CPUFMT 6834, 31.1 mm SL.

Colour in alcohol. Background colour beige to pale yellow. Dorsal region of head and mid-dorsal region of body with dense concentration of melanophores. Iris with scattered melanophores. Region of infraorbital and opercular series beige, with few scattered melanophores, more concentrated on superior half. Region of opercular series retaining guanine pigmentation. Maxilla and gular region with few scattered melanophores, slightly more concentrated on superior half. Flank with melanophores scattered and equally distributed, except on anteroventral half, and on ventral portion of caudal peduncle. Scales on superior third of anterior region of flank with dense concentration of melanophores on posterior margin, conferring reticulate pattern. One dark-brown humeral blotch, conspicuous, shaped as square or vertically elongate rectangle, occasionally with margins somewhat rounded; with equally distributed melanophores, extending two longitudinal scale rows above lateral line and not surpassing it below. Brownish longitudinal midlateral stripe, from vertical through halfway humeral blotch and dorsal-fin origin, to median caudal-fin rays. Fins almost hyaline, with few melanophores on interradial membranes; dark-brown stripe along anal-fin base. Abdominal region, from pectoral-fin origin to pelvic-fin end, without melanophores.

Sexual dimorphism and ontogeny. Two specimens collected in December and April (28.1-31.7 mm SL; presumably males) with contact organs (hooks) on anal and pelvic fins and gill-derived gland. In both specimens, hooks present on distal half of largest unbranched and first three branched anal-fin rays (4-6 small, paired hooks per ray, one per segment, on posterolateral side of each ray, most proximal situated immediately proximal to first branching point and more distal ones located only on posterior branch, if on branched ray); and in lateralmost unbranched and in following four branched pelvic-fin rays (7-12 hooks per ray, one ray per segment, on ventromedial side of each ray, most proximal situated well proximal to first branching point and more distal ones located only on medial branch, if on branched ray). Gill-derived gland formed by fusion of 6-8 most anteroventral external filaments of first gill arch, although former limits between them still obvious. No allometric nor allomeric changes detected, possibly 
due to small available sample. Allochromatic changes include increase in contrast of colour patterns and overall increase in number of melanophores on body. Longitudinal midlateral stripe progressively more intense, deeper and with sharper limits. Also an increase in concentration of guanine and of melanophores dispersed around midlateral stripe, mainly in region between humeral mark and vertical through dorsal-fin origin. Humeral mark also develops sharper and more squarish limits (more diffuse and roundish in young). Countershading, which in young consists only in a few melanophores on distal margin of dorsalmost scales, much more developed in adults. In some adults, first few lateral-line scales with pores bordered by melanophores. No apparent sexual dichromatism.

Etymology. We name Knodus rufford after the Rufford Foundation, which provided the funds that allowed the expedition resulting in the discovery of the two new species described herein (as well as Moenkhausia goya Deprá, Azevedo-Santos, Vitorino Júnior, Dagosta, Marinho \& Benine). A noun in apposition not latinised.

Geographical distribution. Knodus rufford is only know from the ribeirão Dois Irmãos basin, in the rio das Almas basin, upper rio Tocantins, Municipality of Pirenópolis, Goiás State, Brazil (Fig. 5).

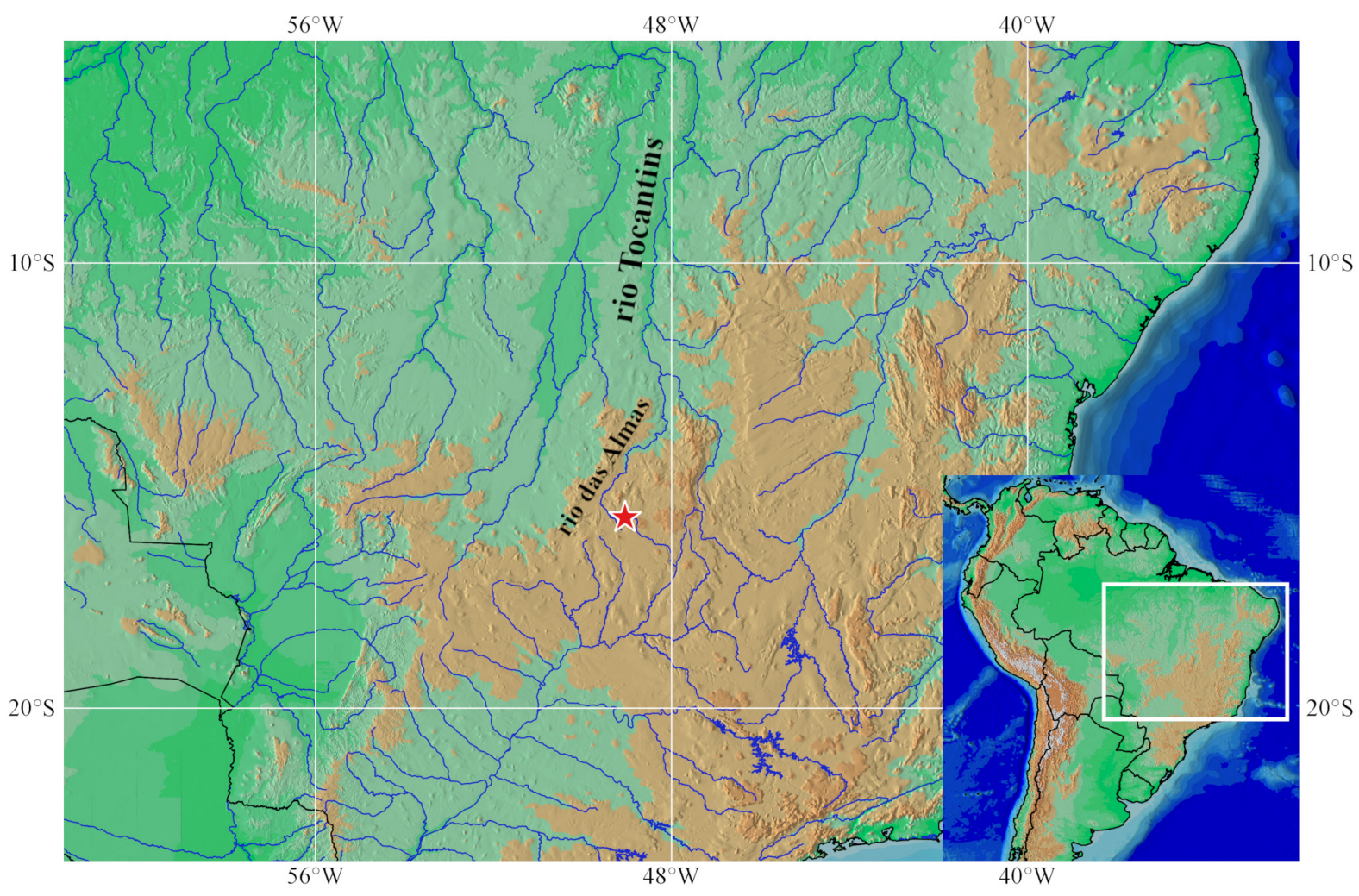

FIGURE 5 I Partial map of South America, showing the known geographic distribution of Knodus rufford and K. obolus. The red star encompasses the type locality and other sampling sites that are too close to be represented as separate points. 
Ecological notes. Knodus rufford occurs in all sorts of aquatic environments within the high-altitude (about $700 \mathrm{~m}$ ) streams of the rio das Almas basin, despite there seems to be some preference for pool habitats where the water flow is less intense and most of the individuals were sampled. Stomach content analyses indicate omnivorous behaviour once both species consumed aquatic and terrestrial invertebrates, plant material, organic and inorganic debris. Disturbances such as habitat degradation and rapid increase of water flow during the rainy season were often observed on sampling sites with occurrence of the species, indicating population-level responses that increase species tolerance to variability of habitat conditions, resources availability and other mortality factors. Therefore, K. rufford fits the classic opportunistic life-history model (Winemiller, 1989) with less specialized requirements in every dimension of its niche.

Conservation status. Knodus rufford is so far only known from the rio das Almas system, an upper rio Tocantins basin tributary. Inside this watershed the species is widely distributed and was recorded at relatively degraded habitats mainly by pasture and mining activities. As no specific threats were detected, K. rufford can be tentatively categorized as Least Concern (LC) following the International Union for Conservation of Nature (IUCN) categories and criteria (IUCN Standards and Petitions Subcommittee, 2017).

\section{Knodus obolus, new species}

urn:1sid:zoobank.org:act:418ED7D0-B390-4C89-910D-104AAEBA59CC

(Figs. 5-8, Tabs. 2-3)

Holotype. NUP 22667, 46.4 mm SL, Brazil, Goiás State, Municipality of Pirenópolis, ribeirão Dois Irmãos, tributary to the rio do Peixe, tributary to the rio das Almas, tributary to the rio Maranhão, tributary to the rio Tocantins, $15^{\circ} 42^{\prime} 50^{\prime}{ }^{\circ} 49^{\circ} 2$ '39”W, 24 Apr 2017, O. Vitorino Júnior.

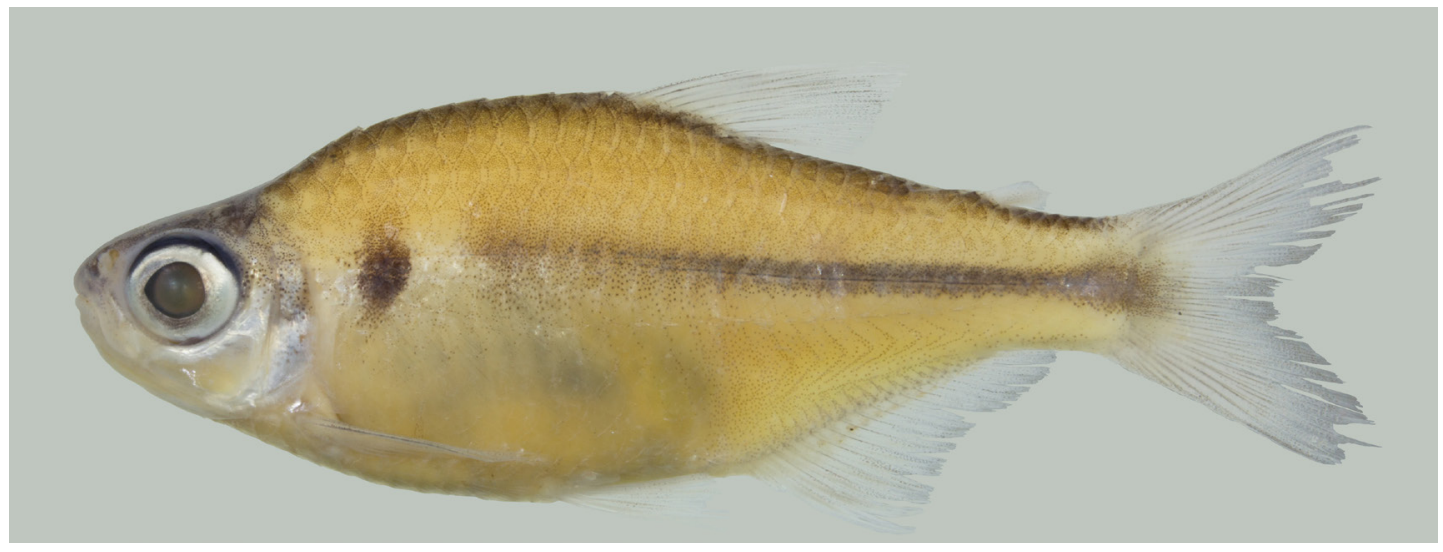

FIGURE 6 I Knodus obolus, holotype, NUP 22667, 46.4 mm SL, ribeirão Dois Irmãos, tributary to the rio do Peixe, tributary to the rio das Almas, tributary to the rio Maranhão, tributary to the rio Tocantins, Municipality of Pirenópolis, Goiás State, Brazil. 


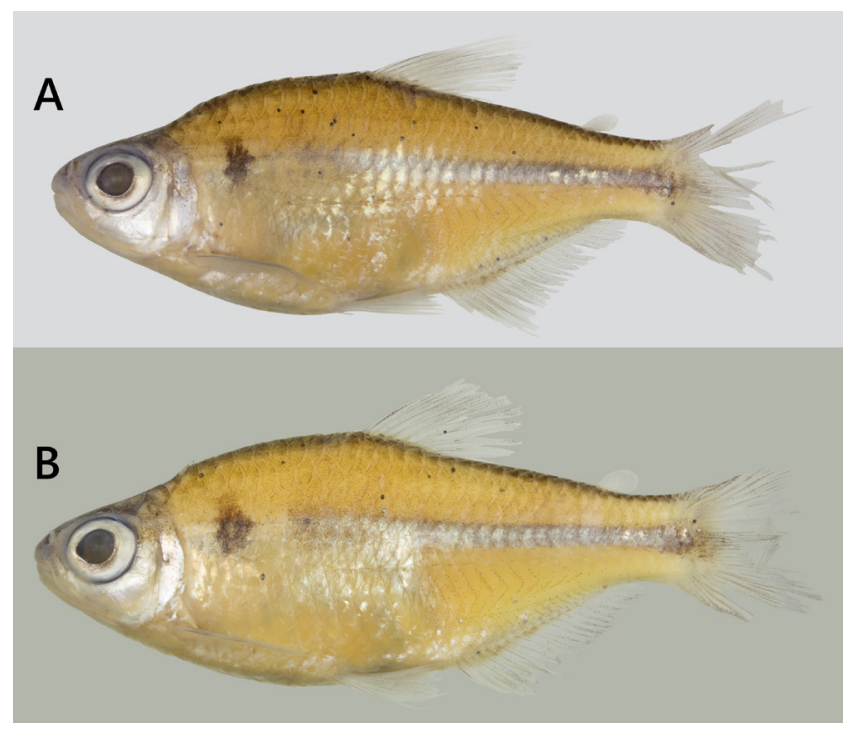

FIGURE 7 I Knodus obolus, paratypes. Ontogenetic and polymorphic variation of the body shape and colour patterns. All from the ribeirão Dois Irmãos drainage, upper Tocantins basin in Pirenópolis, Goiás State, Brazil. A. NUP 22668, 56.9 mm SL. B. NUP 22668, $53.2 \mathrm{~mm}$ SL. C. NUP 22668, 49.6 mm SL. D. NUP 22668, 45.0 mm SL. E. NUP 22668, $33.1 \mathrm{~mm} \mathrm{SL}$.

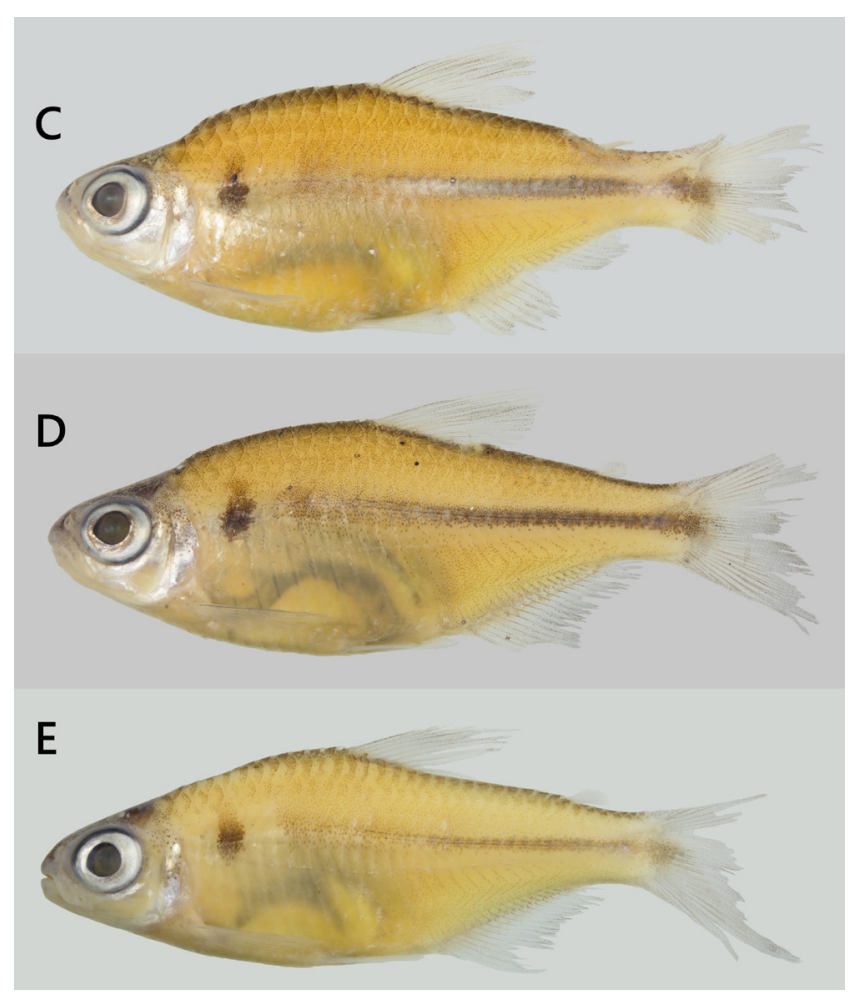

Paratypes. All from Brazil, Goiás State, Municipality of Pirenópolis, ribeirão Dois Irmãos, tributary to the rio do Peixe, tributary to the rio das Almas, tributary to the rio Maranhão, tributary to the rio Tocantins. CPUFMT 6837, 2 c\&s, 48.9-50.3 mm SL, collected with the holotype. CPUFMT 6838, 14, 42.8-56.9 mm SL, collected with the holotype. MCP 54463, 7, 49.2-57.5 mm SL, collected with the holotype. NUP 22663, 7 , 38.1-52.7 mm SL, 1542’50”S 49²'54”W, elevation 702 m, 12 Dec 2016, G. C. Deprá \& O. Vitorino Júnior. NUP 22668, 23, 23.0-56.8 mm SL, collected with the holotype.

Non-type. CPUFMT 6832, 1 (fixed in 90\% ethanol), $32.2 \mathrm{~mm} \mathrm{SL}$, Brazil, Goiás State, Municipality of Pirenópolis, ribeirão das Araras, tributary to the ribeirão Dois Irmãos, tributary to the rio do Peixe, tributary to the rio das Almas, tributary to the rio Maranhão, tributary to the rio Tocantins, $15^{\circ} 42^{\prime} 15^{\prime \prime S} 49^{\circ} 2^{\prime} 12$ "W, elevation $722 \mathrm{~m}, 12$ Dec 2016, G. C. Deprá \& O. Vitorino Júnior.

Diagnosis. Knodus obolus is distinguished from all congeners bearing caudal-fin scales, except K. aff. breviceps (syntopic), K. cupariensis, K. meridae, K. nuptialis, K. orteguasae and K. rufford, and from Bryconacidnus hypopterus, by having usually 4 scales between dorsalfin origin and lateral line (vs. 5-51/2). Knodus obolus is distinguished from $K$. aff. breviceps, K. cupariensis, K. nuptialis and Knodus rufford by having a larger eye, 43.6-47.1\% HL (vs. 36.0-40.7 in K. aff. breviceps, 34.4-43.7 in K. cupariensis, 34.7-43.7 in K. nuptialis and 35.2-38.6 in $K$. rufford); and by having 5-7 cusps at least in some of the inner-series premaxillary and anterior dentary teeth (vs. up to 3 cusps in $K$. rufford). From K. meridae, K. nuptialis and K. orteguasae, by having 16-19 branched anal-fin rays (vs. 12-15 in K. 
meridae and K. nuptialis); dorsal profile of body forming an angle at dorsal-fin origin ( $v s$. uniformly arched); deeper body, 34.6-38.5\% SL (vs. 24.2-32.7 in K. meridae, 22.6-32.3 in K. nuptialis and 26.5-35.0 in K. orteguasae); and larger eye, 43.6-47.1\% HL (vs. 31.6-36.0 in K. meridae and 34.6-42.8 in K. orteguasae). Occasional specimens of Knodus obolus presenting 5 scales between dorsal-fin origin and lateral line may be distinguished from other species with a similar count, except K. figueiredoi, K. gamma, K. megalops and K. smithi, and from Bryconacidnus hypopterus, by the combination of a large eye, 43.6-47.1\% HL, and a deep body, 34.6-38.5\% SL. Knodus obolus is distinguished from K. figueiredoi by having $5-7$ cusps in inner-series premaxillary and anterior dentary teeth (vs. 3); and by having i,6,i pelvic-fin rays ( $v$ s. i,5,i). From K. gamma, K. megalops and K. smithi, by having 16-19 branched anal-fin rays (vs. 22-25 in K. gamma, 18-24 in K. megalops and 23-27 in K. smithi). Additionally, K. obolus is distinguished from $K$. megalops by presenting hooks only on the first 4-8 branched anal-fin rays of mature males ( $v$ s. first 11-12 branched rays). Additionally, the completely pored lateral line distinguishes $K$. obolus from $K$. borki (incomplete, $6-14$ perforated scales) and $K$. delta (8-12). The absence of distinct marks from all fins distinguishes $K$. obolus from $K$. dorsomaculatus (a black band present on proximal third of dorsal fin), K. cupariensis and K. geryi (a black spot on the base of each caudal-fin lobe), K. pasco (a horizontal black band present on the middle of dorsal fin) and $K$. savannensis (a distinct black band running along middle caudal fin rays and extending through distal half of ventral caudal-fin lobe). The presence of 2-3 maxillary teeth distinguishes $K$. obolus from $K$. pasco (5-6). The presence of 3-31/2 scales between lateral line and pelvic-fin origin distinguishes $K$. obolus from $K$. shinahota (5). The presence of normally developed skin folds on the base of the first few branched anal-fin rays ( $v s$. highly developed) and the absence of a second humeral blotch ( $v$ s. presence) distinguishes $K$. obolus from K. tiquiensis. The absence of breeding tubercles ( $v$ s. presence) distinguishes K. obolus from K. nuptialis.

Description. Morphometric data in Tab. 3. Body compressed, greatest body depth anterior to vertical through dorsal-fin origin. Dorsal profile of body convex from upper lip to vertical through nostril; almost straight from this point to base of supraoccipital bone; concave from its base to distal tip of supraoccipital process. Ascending convex from tip of supraoccipital process to dorsal-fin origin; descending straight along dorsalfin base; continuing almost straight to adipose-fin origin; slightly concave along caudal peduncle. Ventral profile of body convex from lower lip to anal-fin origin; straight along anal-fin base; and slightly concave along caudal peduncle.

Jaws slightly retrognathous, mouth terminal. Premaxillary teeth in two rows; outer row with $3^{\star}(2), 4(2)$, or $5(82)$ tri- to pentacuspid teeth; inner row with $4^{\star}(12)$ pentato heptacuspid teeth (seven cusps, when present, on the third and, occasionally on the second tooth from symphysis). Posterior margin of maxilla posterior to vertical through anterior margin of orbit. Maxilla with 2(8), or $3^{\star}(3)$ penta- to hexacuspid teeth; rarely one tricuspid teeth. Dentary with $4^{\star}(12)$ large pentacuspid, and $1^{\star}(7)$ tricuspid teeth, gradually decreasing in size, followed by up to five conical and abruptly smaller teeth. Central cusp longer than lateral ones.

Scales cycloid, with few radii (1-3); circuli markedly anterior and marginally (dorsally and ventrally). Lateral line completely pored with $35^{\star}(4), 36(6)$, or 37(2) perforate scales. Scale rows between dorsal-fin origin and lateral $4 \frac{1}{2} 2^{\star}(11)$, or $5 \frac{1}{2}(1)$. Scale rows between 
lateral line and pelvic-fin insertion 3(4), or $3 \frac{1}{2^{*}}(8)$. Predorsal series with 9(1), 91/2(1), $10(5), 10 \frac{1}{2}(2)$, or $11^{\star}(3)$ scales in midline. Single row of up to 15 scales covering base of anal-fin rays. Circumpeduncular scales $14^{\star}(12)$. A single series of 15(6), 16(4), 17(2), 18(2) scales covering the entire anal-fin base.

Dorsal-fin rays ii, $7, \mathrm{i}(2)$ or ii, $8^{\star}(8$; in 4 , last element in process of bifurcation). Adipose fin present. Pectoral-fin i,9,ii(1), i,10, $i^{\star}(9)$, or i,10,ii(2) distal tip of rays not reaching pelvic-fin origin. Pelvic-fin rays $\mathrm{i}, 6, \mathrm{i}^{\star}(11)$, or $\mathrm{i}, 7(1)$, distal tip not reaching anal-fin origin. Anal-fin rays iii,16(6), or iii,17*(6). Anal and pelvic fin of mature males with bony hooks, as seen in entire specimens (but see Tab. 2 for c\&s specimens). Caudal fin bifurcate, lobes approximately of same size, i, $9 / 8$, i rays.

First gill arch with $6^{\star}(8)$, or $7(4)$ rakers on epibranchial, 1(12) on intermediate cartilage, and $9(1), 10\left({ }^{\star} 5\right), 11(5)$, or 12(1) on cerato+hipobranchial. For a more detailed gill-raker count of the c\&s specimen, see Tab. 2. Branchiostegal rays 4(12).

TABLE 3 । Morphometric data of Knodus obolus. SD = standard deviation; $\mathrm{N}$ = number of specimens.

\begin{tabular}{|c|c|c|c|c|c|}
\hline & \multirow[t]{2}{*}{ Holotype } & \multicolumn{4}{|c|}{ Paratypes } \\
\hline & & $\mathbf{N}$ & Range & Mean & SD \\
\hline Standard length & 46.4 & 11 & $33.3-53.8$ & 45.9 & - \\
\hline \multicolumn{6}{|l|}{ Percentages of standard length } \\
\hline Body depth & 39.9 & 11 & $36.6-40.1$ & 38.8 & 1.0 \\
\hline Predorsal distance & 54.3 & 11 & $52.4-56.3$ & 54.4 & 1.4 \\
\hline Prepectoral distance & 25.2 & 11 & $24.7-27.6$ & 26.0 & 0.9 \\
\hline Prepelvic distance & 50.9 & 11 & $48.3-53.3$ & 50.9 & 1.4 \\
\hline Preanal distance & 66.6 & 11 & $65.2-68.4$ & 66.7 & 1.1 \\
\hline Caudal-peduncle depth & 13.1 & 11 & $12.1-14.0$ & 13.0 & 0.6 \\
\hline Caudal-peduncle length & 13.1 & 11 & $12.0-14.6$ & 12.9 & 0.8 \\
\hline Dorsal-fin base length & 13.8 & 11 & $13.0-15.0$ & 14.0 & 0.6 \\
\hline Dorsal-fin length & 28.2 & 11 & $22.8-27.5$ & 25.9 & 1.7 \\
\hline Pectoral-fin length & 23.9 & 11 & $23.0-24.8$ & 23.6 & 0.5 \\
\hline Pelvic-fin length & 18.1 & 11 & $17.0-18.6$ & 17.9 & 0.5 \\
\hline Anal-fin base length & 28.9 & 11 & $25.9-29.2$ & 27.8 & 1.2 \\
\hline Anal-fin length & 17.5 & 11 & 15.8-19.4 & 17.7 & 1.3 \\
\hline Orbit to dorsal-fin origin & 40.3 & 11 & $38.0-42.2$ & 40.3 & 1.1 \\
\hline Dorsal-fin origin to caudal peduncle & 50.4 & 11 & $49.5-53.6$ & 51.2 & 1.4 \\
\hline Head depth & 26.3 & 11 & $25.5-30.4$ & 27.0 & 1.4 \\
\hline Head length & 26.1 & 11 & $25.4-28.5$ & 26.4 & 0.9 \\
\hline \multicolumn{6}{|l|}{ Percentages of head length } \\
\hline Orbital diameter & 43.8 & 11 & $41.3-46.3$ & 43.2 & 1.5 \\
\hline Snout length & 27.3 & 11 & $25.4-29.5$ & 27.1 & 1.1 \\
\hline Interorbital width & 33.9 & 11 & $32.4-35.1$ & 34.0 & 1.0 \\
\hline Upper-jaw length & 40.5 & 11 & $37.5-40.5$ & 39.4 & 1.0 \\
\hline
\end{tabular}


Osteology. General appearance of c\&s specimen shown in Fig. 8. Meristic osteological characters are summarised in Tab. 2. Rhinosphenoid ossified (Fig. 8); epiphyseal branch of the laterosensory canal present. Contralateral frontals contacting along about $60 \%$ of distance between mesethmoid and epiphyseal bar, with right frontal bearing expansion over left one. Anterior fontanelle length about 40\% posterior fontanelle length. Posteromedial corner of parietal pointed. Parasphenoid bar strongly arched. Anteroventral process of mesethmoid well developed, nested between contralateral premaxillae. Pharyngobranchial 2 bearing two teeth, almost as long as pharyngobranchial 3. Ossifications dorsal to cartilage between basibranchials 2-3 present. Ceratohyal with shallow notch at the articulation with branchiostegal rays 2-3.

Colour in alcohol. Background colour beige to pale yellow. Dorsal region of head and middorsal region of body with dense concentration of melanophores. Few scattered melanophores around pupil. Region of infraorbital and opercular series beige, retaining guanine pigmentation, and with few scattered melanophores, more concentrated on superior half. Maxilla and gular region with few scattered melanophores, slightly more concentrated on superior half. Flank with melanophores scattered and equally distributed, except on anteroventral half, and on ventral portion of caudal peduncle. Central portion of humeral blotch conspicuous, roundish, dark-brown, from which less conspicuous projections of variable shapes (Figs. 6-7) extend dorsally two longitudinal scale rows above lateral line and ventrally, not past the lateral line. Brownish longitudinal midlateral stripe, from vertical through halfway opercle and dorsal-fin origin, to median caudal-fin rays. Fins hyaline, with melanophores on interradial membranes. Abdominal region, from pectoral-fin origin to pelvic-fin end, without melanophores.

Sexual dimorphism and ontogeny. Holotype and other four specimens collected in December and April (33.3-53.8 mm SL; presumably males) with contact organs (hooks) on anal and pelvic fins and gill-derived gland. In all specimens, hooks present on distal half of largest unbranched and first $4(1,33.3 \mathrm{~mm} \mathrm{SL}), 5^{\star}(1), 6(2,53.5-53.8$

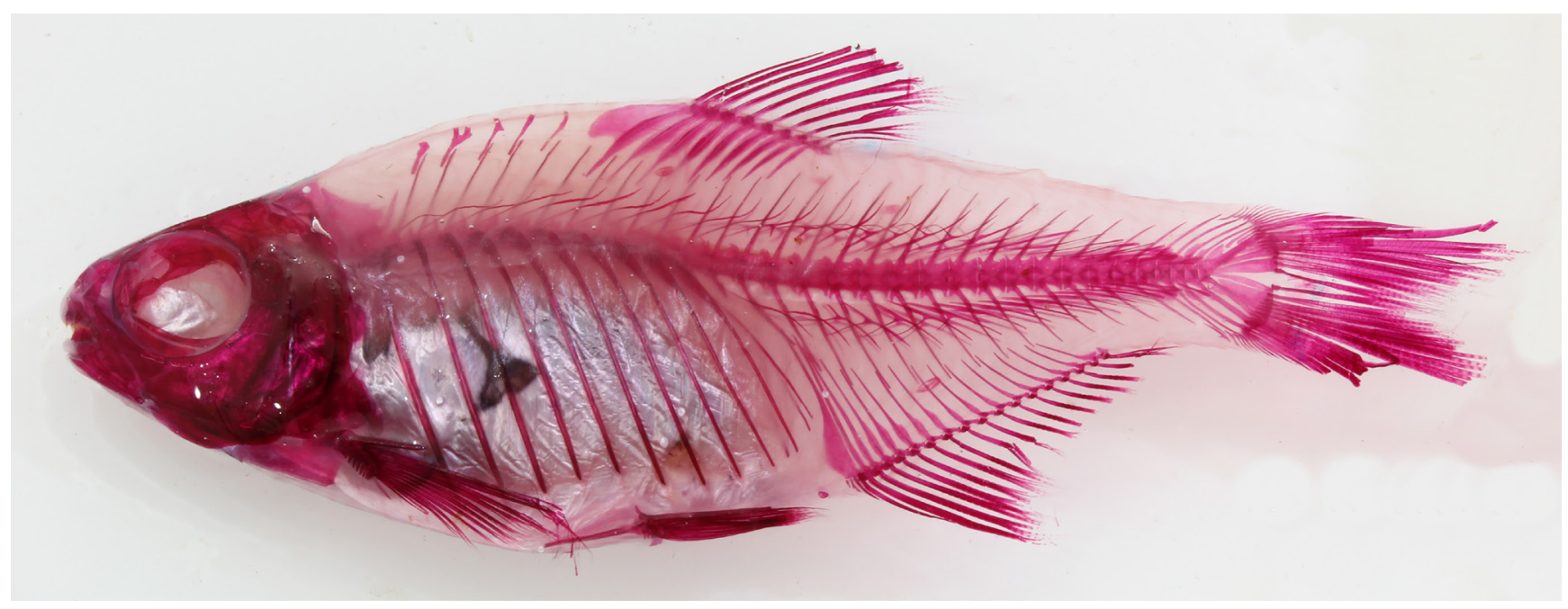

FIGURE 8 | Knodus obolus, c\&s paratype, CPUFMT 6837, 50.3 mm SL. 
$\mathrm{mm} \mathrm{SL})$ or $8(1,45.4 \mathrm{~mm} \mathrm{SL})$ branched anal-fin rays (7-10 small, paired hooks per ray, one or two per segment, on posterolateral side of each ray, most proximal situated well proximal to first branching point and more distal ones located only on posterior branch, if on branched ray); and in all pelvic fin-rays (three specimens, 33.0-53.5 mm SL), or in all branched (holotype) or in $2^{\text {nd }}-4^{\text {th }}$ branched (one specimen, $45.4 \mathrm{~mm} \mathrm{SL}$ ) pelvic-fin rays (12-19 hooks per ray, one ray per segment, on ventromedial side of each ray, most proximal situated well proximal to first branching point and more distal ones located only on medial branch, if on branched ray). Gill-derived gland formed by fusion of 7-8 most anteroventral external filaments of first gill arch; former limits between them either still obvious or faded. The sample analysed is not large enough to warrant statistical support for the allometric and allomeric changes observed. However, some characters seem to be correlated with the SL: pre-pectoral distance in females (negative allometry, $\mathrm{R}^{2}=0.73$ ); pectoral-fin length and pelvic-fin length in females (positive, 0.46 and 0.72 , respectively); anal-fin length (positive in females, 0.82; negative in males, 0.87); orbitdorsal-fin origin, head depth, head length and orbital diameter in males (respectively, positive, 0.52 ; negative, 0.54 ; negative, 0.84 ; and negative, 0.85 ); and interorbital distance in females (positive, 0.45 ). Among meristic characters, the total number of external gill rakers in K. obolus seems to be subject to positive allomery, though the sample available to us lacked a sufficient number of smaller specimens, as to permit a proper statistical test of that affirmation. Allochromatic changes include an increase in the contrast of colour patterns and an overall increase in the number of melanophores on the body. The longitudinal midlateral stripe becomes progressively more intense, deeper and with sharper limits. There is also an increase in the concentration of guanine and of the melanophores dispersed around the stripe, mainly in the region between the humeral mark and the vertical through the dorsal-fin origin and on the longitudinal midlateral stripe (guanine). The humeral mark also develops sharper limits (more diffuse in the young). The countershading, which in the young consists only in a few melanophores on the distal margin of the dorsalmost scales, in adults becomes much more developed. No apparent sexual dichromatism.

Etymology. We name Knodus obolus after Charon's obol, a silver coin that the Greek would place in the mouth of a deceased person before burial, so that their soul could pay Charon, the ferryman, to cross the river separating the world of the living from the world of the dead. It is a reference to the deep body and silvery colouration of $K$. obolus, which is the second species from the rio das Almas basin (river of the souls, in Portuguese) to be named in allusion to this myth, the first being Retroculus acherontos Landim, Moreira \& Figueiredo (2015). The Latin word obolus derives from the Greek oßß入ós, and is to be treated as a latinised noun in the nominative case.

Geographical distribution. Knodus obolus is so far only known from the ribeirão Dois Irmãos basin, in the rio das Almas basin, upper rio Tocantins, Municipality of Pirenópolis, Goiás State, Brazil (Fig. 5).

Ecological notes. Knodus obolus occurs in all sorts of aquatic environments within the high-altitude (about $700 \mathrm{~m}$ ) streams of the rio das Almas basin, despite there seems to be some preference for pool habitats where the water flow is less intense and most of 
the individuals were sampled. Stomach content analyses indicate omnivorous behaviour once both species consumed aquatic and terrestrial invertebrates, plant material, organic and inorganic debris. Disturbances such as habitat degradation and rapid increase of water flow during the rainy season were often observed on sampling sites with occurrence of the species, indicating population-level responses that increase species tolerance to variability of habitat conditions, resources availability and other mortality factors. Therefore, K. obolus fits the classic opportunistic life-history model (Winemiller, 1989) with less specialized requirements in every dimension of its niche.

Conservation status. Knodus obolus is so far only known from the rio das Almas river system, an upper rio Tocantins basin tributary. Inside this watershed the species is widely distributed and was recorded at relatively degraded habitats mainly by pasture and mining activities. As no specific threats were detected, K. obolus should be tentatively categorized as Least Concern (LC) following the International Union for Conservation of Nature (IUCN) categories and criteria (IUCN Standards and Petitions Subcommittee, 2017).

Allomery in Knodus species. Most Knodus species analysed herein present $4 \frac{1}{2}-5 \frac{1}{2}$ (mode 5) scale series between dorsal-fin origin and lateral line. In species other than $K$. aff. breviceps, $K$. obolus and $K$. rufford, only one small specimen of $K$. victoriae and another of $K$. sp. B presented 4 rows. Only three large specimens of $K$. aff. breviceps presented 6 rows, while most specimens of $K$. sp. G presented 6 or $6 \frac{1}{2}$. Thus, in comparison with the other species analysed herein, $K$. rufford and $K$. obolus present few scale rows between dorsal-fin origin and lateral line, with ranges of $4-4 \frac{1}{2}$ and $4-5$ (mode $4 \frac{1}{2}$ ), respectively. More interestingly, $K$. aff. breviceps, $K$. sp. B and $K$. sp. G present ranges of $4-6,4 \frac{1}{2}-51 \frac{1}{2}$ (rarely 4 ) and $5 \frac{1}{2}-61 / 2$, respectively, but with averages varying according to SL. In other words, the number of scale series in these species is positively allomeric. Fig. 9 shows a graphic representation of a regression analysis of this character in $K$. aff. breviceps.

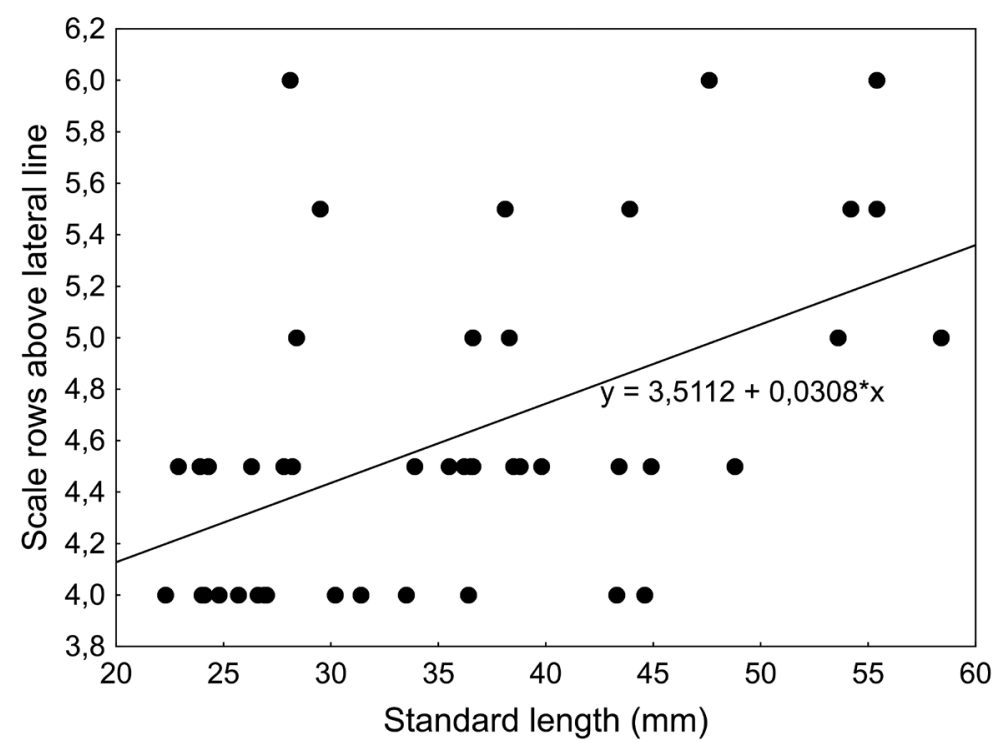

FIGURE 9 I Knodus aff. breviceps, regression analysis of the number of scale series between dorsal-fin origin and lateral line. $\mathrm{R}^{2}=0.26 ; \mathrm{p}=0.0003$. 


\section{DISCUSSION}

The overwhelming convergence of phenotypic characters seen in Characidae (e.g., caudal-fin squamation, colouration patterns, degree of lateral-line development, presence of insemination, tooth shape etc.), which confuses so much its classification, seems to be a necessary consequence of its species richness. That is, because so many different lineages with recent common ancestors still survive, the divergence between them is not sufficient to delimit monophyletic genera unequivocally based on easily observed, unique morphological characters. Thus, we must rely on combinations of characters that are evolutionarily very plastic. The consequence is that species belonging to different lineages frequently present the same combinations of characters.

Of the 340 species included in Stevardiinae (Fricke et al., 2020), about half (164) are placed in one of the following genera: the Diapomini Bryconamericus (55 species), Knodus (30) and Diapoma Cope, 1894 (14); the Hemibryconini Hemibrycon Günther, 1864 (52); and the Eretmobryconini Eretmobrycon Fink, 1976 (12). All of those taxa present a generalised characid morphology (although some species of Bryconamericus, Eretmobrycon, Knodus and Diapoma present interesting specialisations in the jaws, teeth, opercular bones, caudal-fin squamation or dimorphic characters). Perhaps because of their generalised nature, the diagnoses between those genera are not well marked, mainly when we compare Bryconamericus to each of the other taxa. An example of this confusion is the fact that García-Melo et al. (2018) found several species of Bryconamericus to belong, in fact, in Hemibrycon. This kind of advance in the understanding of the stevardiine phylogeny was achieved by molecular analyses such as that of Thomaz et al. (2015). We hope that soon enough those analyses can present a full hypothesis of relationships between the members of the subfamily.

Meanwhile, new species descriptions, such as the ones presented herein, often rely exclusively on morphological data, which, until tissue samples are available, must be sufficient to the generic allocation of the species. In this context, the use of the definitions of Knodus, Bryconamericus and Bryconacidnus by Eigenmann $(1918,1927)$ and Eigenmann, Myers (1929) facilitated the tentative allocation of K. rufford and K. obolus, although those definitions do not apply to monophyletic groups (see Introduction). This is the same approach used in descriptions of species in the stethaprionine genera Astyanax Baird \& Girard, 1854, Hyphessobrycon Durbin, 1908, Moenkhausia Eigenmann, 1903, Hemigrammus Gill, 1858 and Jupiaba Zanata, 1997, for instance.

Besides fitting the diagnosis of Knodus, K. rufford and K. obolus are found in the upper rio Tocantins basin, which lies within the typical range of the genus (in contrast with genera such as Bryconamericus and Bryconacidnus, which are rare or absent from the region). As pointed out by Bertaco, Carvalho (2010) and Deprá et al. (2018a), the upper rio Tocantins (sensu Ribeiro et al., 1995, i.e., including only the Maranhão and Paranã river basins) harbours a high number of endemic species, which rises to 53 including the two species described herein. This represents $59.5 \%$ of the total endemic species of the broader upper Tocantins biogeographic region sensu Dagosta, De Pinna (2017, 2019), possibly giving the region the highest concentration of endemic species in the Amazon basin. Those numbers will certainly rise (e.g., Cláudio H. Zawadzki, pers. comm.). In fact, the other species of Knodus reported from the region, $K$. aff. breviceps, belongs to a widespread species complex including two nominal species, viz. K. breviceps and $K$. 
chapadae, defined by the presence of a long, pointed snout. Knodus breviceps was sampled during the Thayer Expedition to Brazil (1865-66) and, according to Isbrücker (1973), the type locality is "Rio Araguaia drainage, upper course of Rio Vermelho at Goias" (see Higuchi, 1996 for more details). The type specimens of $K$. breviceps, as suggested by the etymology of the name, have a short head (21.8-24.1\% in SL, vs. 24.7-26.1 in K. aff. breviceps from the rio das Almas basin). Thus, it is possible that the ongoing research by KMF will reveal that the specimens from the upper rio Tocantins basin in fact belong to another undescribed species.

Young Knodus aff. breviceps are very similar to K. rufford of similar sizes, especially in the occasional presence of only four scale series between the dorsal-fin origin and the lateral line (see 'Allomery in Knodus species' above and compare Figs. 3 and 10). Also, young $K$. breviceps do not show a particularly pointed snout typical of the $K$. breviceps/chapadae species complex. However, some characters are useful to distinguish these species when younger specimens are considered. First, K. rufford has 11-12 circumpeduncular scale rows (vs. 14-15). Second, in K. rufford the humeral mark has well defined margins all around ( $v$ s. diffuse dorsally and ventrally in $K$. breviceps) and a square to vertically rectangular shape ( $v s$. obliquely rectangular). Third, the mouth cleft of $K$. rufford is somewhat more ventral. Fourth, the neuromasts of the supraorbital lateralis canal of $K$. breviceps are situated in a shallow groove not present in K. rufford.

The osteological approach adopted herein aimed at comparing the two new species described, yielding interesting differences, including the size and presence or absence of teeth in pharyngobranchial 2. Both species presented an anterior contact between the contralateral frontals, as reported by Esguícero, Castro (2014) for some other species of Knodus, but with one of the antimeres overlapping the other, a character that was not reported by those authors. The two species presented similar amounts of vertebrae, although only K. rufford presented a vertebra of type C (Tab. 2; see Material and Methods). Vertebrae presenting a shape different from the typical abdominal and caudal vertebrae (respectively, types A and D) exist in different fish groups (e.g., Weitzman, 1962, fig. 14A-C; GCD, pers. obs.). Although we cannot conclude at the present
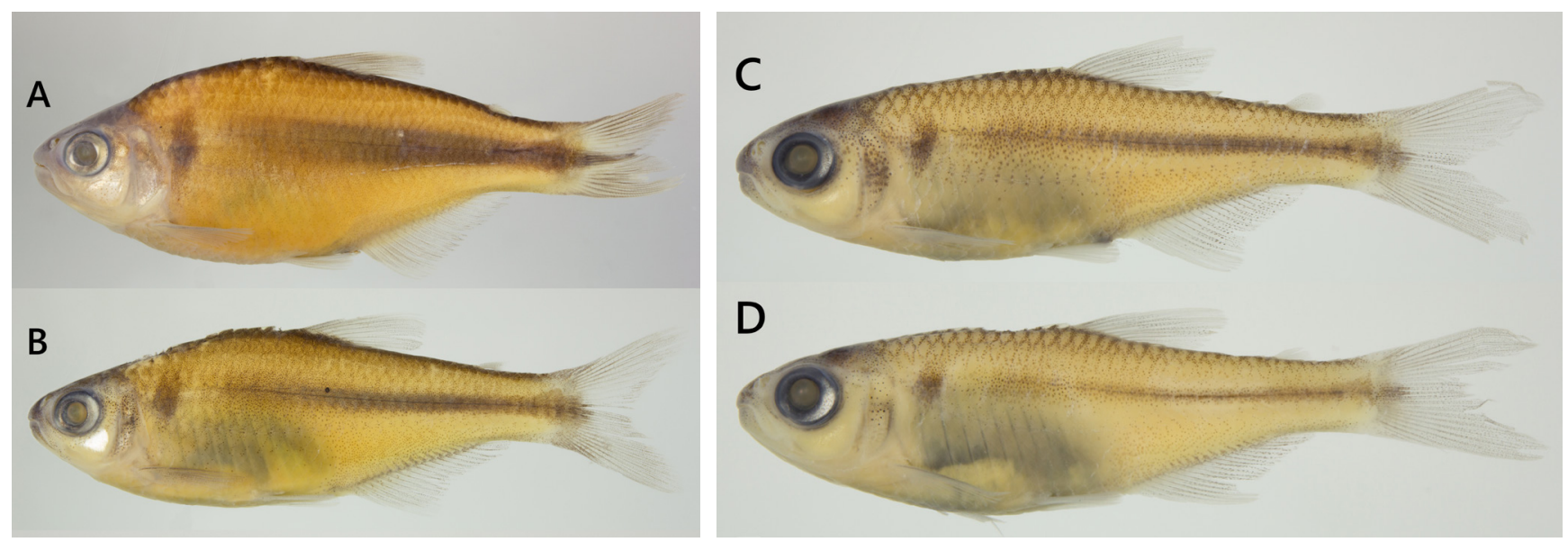

FIGURE 10 I Knodus aff. breviceps from the rio das Almas basin, upper Tocantins basin (collected in syntopy with K. obolus and K. rufford). A. NUP 22666, 55.3 mm SL. B. NUP 22662, 42.0 mm SL. C. NUP 22665, 28.2 mm SL. D. NUP 22665, 23.9 mm SL. 
whether the difference observed between $K$. rufford and K. obolus is taxonomically relevant or not, we encourage other researchers to adopt the more detailed methodology for counting vertebrae described herein, which may help to distinguish between other pairs of species in the future. Other character set that has been very seldom explored in taxonomic literature, but may prove useful, is the amount of gill rakers on both internal and external sides of all gill arches. Knodus rufford presented a smaller number of gill rakers in almost all portions of all gill arches, in comparison with $K$. obolus. The larger sample in which we counted the number of external rakers in the first arch present the same pattern (13-16 total rakers in K. rufford, vs. 17-19 in K. obolus). However, we are cautious about the potential of that character as diagnostic between the two species, as it seems to exist a positive allomery in it, at least in K. obolus.

The previously unreported existence of allomeric characters in Characidae, herein detected in the number of scale rows between dorsal-fin origin and lateral line, deserves further analyses, as it may be more widespread within the family and affect other meristic characters (most likely the number of gill rakers). A practical consequence of this phenomenon is that direct comparisons between specimens of different body sizes must be seen with caution, which is also true for morphometric characters, considering that allometry is ubiquitous. Whenever possible, species descriptions must count on specimens of a broad size range, in order to avoid false diagnostic characters. On the other hand, the recognition of characters that change ontogenetically opens new possibilities, as different ontogenies should be regarded as informative characters.

Secondary sexual characters are another source of data that can help distinguishing between species that are closely related or otherwise morphologically similar. The two species described herein present different amounts of anal-fin rays that bear hooks, as well as different amounts of hooks in each ray, distributed to different extents along them. Using those characters to diagnose species requires a number of fully mature specimens as a guarantee that we are not observing partially developed secondary sexual structures. In some species of Stevardiinae, including some Knodus, all of such structures disappear after the breeding season (Menezes, Marinho, 2019). The same is true of Bryconamericus coeruleus Jerep \& Shibatta, 2017, in which specimens with hooks are very common in August, rare in January and February and non-existent in April (GCD, pers. obs.).

However, in some Stevardiinae the hooks and gill gland seem to be maintained for life after first maturation. Planaltina Böhlke, 1954 species analysed by Deprá et al. (2018b), for instance, presented hooks and gill glands in January, February, April, July, October and November. Specimens collected in other months were mostly unavailable. Of course, this could be evidence that Planaltina species can breed all the year long, which has not been checked through gonadal analysis yet. In fact, this is the case of the Knodus species from the upper rio Tocantins basin, as one of the authors (OBVJ) verified by analysing several specimens of $K$. rufford, $K$. obolus and $K$. aff. breviceps collected bimonthly in the years of 2016-2017 (unpublished data). Unfortunately, only the specimens analysed herein were checked for the presence of hooks and gill glands, thus we are unable to conclude whether those structures are kept for life or not. In a Darwinian sense, sexual characters will be seasonal if out of the breeding season they represent a cost in terms of individual fitness higher than the cost of reabsorbing them and redeveloping them in the next breeding season. The hooks, though small, 
possibly affect natation negatively, while the presence of a gill gland reduces the area for absorption of oxygen.

Comparative material examined. Bryconadenos tanaothoros: Brazil: MZUSP 85852, 41.3 mm SL, holotype. Bryconadenos weitzmani: Brazil: MZUSP 98666, 40.7 mm SL, holotype. Bryconamericus alpha: Venezuela: AUM 54052, 2, 38.6-39.2 mm SL. Bryconamericus beta: Colombia: FMNH 56648, $43.2 \mathrm{~mm} \mathrm{SL}$, holotype; FMNH 56649, 40.2-47.8 mm SL, paratypes. Bryconamericus cinarucoense: Venezuela. All from Apure, Pedro Camejo, río Cinaruco. MCNG 39801, 29, 23.2-27.5 mm SL; MCNG 41346, 13, 19.6-29.2 mm SL; MCNG 45016, 4, 16.7-24.2 mm SL. Venezuela: ANSP 191136, 22.8 mm SL. Bryconamericus deuterodonoides: Venezuela: INHS 60365, 9, 22.544.0 mm SL; INHS 55421, 11, 16.5-40.3 mm SL; INHS 28933, 4, 27.4-50.7 mm SL. Bryconamericus macrophthalmus: Venezuela: MBUCV 29392, 39.0 mm SL, holotype; MBUCV 11381, 21.9-47.6 mm SL, paratypes. Bryconamericus orinocoensis: Venezuela: MBUCV 29464, 27.0 mm SL, holotype; MBUCV 25834, 27.9-29.8 mm SL, paratypes. Bryconamericus singularis: Venezuela: MBUCV 33029, 21.5-24,33 mm SL, paratypes. Bryconamericus subtilisform: Venezuela: MBUCV 29393, $55.3 \mathrm{~mm}$ SL, holotype; MBUCV 29393, 27.9-38.3 mm SL, paratypes. Bryconamericus yokiae: Venezuela: MBUCV 29540, 65.5 mm SL, holotype; MBUCV 20273, 27.9-56.7 mm SL, paratypes. Knodus albolineatus: Brazil: NMW 83365:1, $70.1 \mathrm{~mm}$ SL, syntype. Knodus angustus: Brazil: MCZ 89966, 25.3-39.0 mm SL, syntypes; USNM 120247, 38.5 mm SL, syntype. Knodus breviceps: Brazil: MCZ 20692, 52.0-66.8 mm SL, syntypes. Knodus aff. breviceps: Brazil: CPUFMT 6831, 4, 29.8-46.1 mm SL, CPUFMT 6836, 6, 35.7-48.7 mm SL, NUP 22662, 1, 42.0 mm SL, NUP 22664, 1, 35.4 mm SL, NUP 22665, 31, 23.1-38.0 mm SL, NUP 22666, 3, 54.6-55.5 mm SL. Knodus calliurus: Brazil: ZMB 23684, 33.2 mm SL, holotype. Knodus caquetae: Colombia: ANSP 71670, 50.0 mm SL, holotype; ANSP 71671, $38.1 \mathrm{~mm}$ SL, paratype. Knodus chapadae: Brazil: ANSP 21828, $59.1 \mathrm{~mm}$ SL, holotype; ANSP 21829, 42.6 mm SL, paratype. Knodus delta: Ecuador: ZMH 1473, 34.0 mm SL, holotype. Knodus dorsomaculatus: Brazil: MZUSP 102823, 48.0 mm SL, holotype. Knodus figueiredoi: Brazil: LIRP 10241, 31.7-19.3 mm SL, paratypes. Knodus gamma: Ecuador: ZMH 1861, 48.5 mm SL, holotype; ZMH 2211, 46.7-48.2 mm SL, paratypes. Knodus geryi: Brazil: MZUSP 83354, 63.4 mm SL, holotype; MZUSP 78863, 18.4-64.8 mm SL, paratypes. Knodus hypopterus: Colombia: ANSP 70505, $32.5 \mathrm{~mm}$ SL, holotype. Knodus jacunda: Brazil: ANSP 39292, $22.1 \mathrm{~mm}$ SL, holotype. Knodus meridae: Venezuela: BMNH 1908.5.29.148, $44.0 \mathrm{~mm}$ SL, holotype. Knodus mizquae: Bolivia: ANSP 69176, 32.2 mm SL, holotype; ANSP 69178-69191, 23.4-32.8 mm SL, paratypes. Knodus moenkhausii: Paraguay: CAS 55104, 23.5-28.7 mm SL, paratypes; CAS 55103, $36.1 \mathrm{~mm}$ SL, paratype; AMNH 1463, 26.6-30.0 mm SL, paratypes; FMNH 52601, 31.9-33.0 mm SL, paratype. Knodus nuptialis: Brazil: MZUSP 124829, $46.5 \mathrm{~mm}$ SL, holotype. Knodus orteguasae: Colombia: ANSP 70504, $55.6 \mathrm{~mm}$ SL, holotype. Knodus savannensis: Brazil: USNM: 196088, 30.4 mm SL, holotype. Knodus septentrionalis: Ecuador: ZMH 2261, $50.1 \mathrm{~mm}$ SL, holotype. Knodus shinahota: Bolivia: LIRP 5722, 33.7 mm SL, holotype. Knodus smithi: Brazil: ANSP 39293, 25.2 mm SL, holotype; ANSP 39294-39297, 18.5-24.0 mm SL, paratypes. Knodus tiquienesis: Brazil: MZUSP 88059, 72.6 mm SL, holotype. Knodus victoriae: Brazil: NMW 57823, 29.0244.6 mm SL, syntypes. Moenkhausia lepidura hasemani: Brazil: FMNH 55055, 44.4 mm 
SL, holotype. Knodus sp. A: Brazil: NUP 21928, 22, 29.7-34.1 mm SL. Knodus sp. B: Brazil: NUP 8382, 7, 29.4-47.8 mm SL. Knodus sp. C: Brazil: NUP 7608, 6, 34.5-40.5 mm SL. Knodus sp. D: Brazil: NUP 15283, 3, 20.5-42.2 mm SL. Knodus sp. E: Brazil: NUP 11618, 4, 25.3-40.2 mm SL. Knodus sp. F: Brazil: NUP 18593, 25, 33.5-48.6 mm SL. Knodus sp. G: Brazil: 8450, 51, 25.3-57.7 mm SL.

\section{ACKNOWLEDGMENTS}

We thank Hugo Message for kindly making the regression analysis. To Carla Pavanelli and Marli Campos for technical support at the Coleção Ictiológica do Nupélia. The type-material was collected during expeditions of the "Projeto Pirapitinga" nongovernmental organization, funded by the Rufford Foundation (\#19213-1 and \#235952). The authors were funded by Conselho Nacional de Desenvolvimento Científico e Tecnológico (CNPq) (GCD, grants\# 141005/2015-7) (RRO, grant\#154475/2018-1), and by Coordenação de Aperfeiçoamento de Pessoal de Nível Superior (Capes) (OBVJ). KMF received financial support from Fundação de Amparo à Pesquisa do Estado de São Paulo (Fapesp, grant\# 02/05464-0). The Núcleo de Pesquisas em Limnologia, Ictiologia e Aquicultura (Nupélia) and the Programa de Pós-Graduação em Ecologia de Ambientes Aquáticos Continentais (PEA) provided logistic support.

\section{REFERENCES}

- Berry FH, Barrett I. Gill raker analysis and speciation in the thread herring genus Opisthonema. Inter-American Tropical Tuna Commission Bulletin. 1963; 7(2):110 90.

- Bertaco VA, Carvalho FR. New species of Hasemania (Characiformes: Characidae) from central Brazil, with comments on the endemism of upper rio Tocantins basin, Goiás State. Neotrop Ichthyol. 2010; 8(1):27-32. https://doi.org/10.1590/S167962252010000100004

- Chen L-C. Systematics, variation, distribution, and biology of rockfishes of the subgenus Sebastomus (Pisces, Scorpaenidae, Sebastes). Bull Scripps Inst Oceanography. 1971; 18:1-115.

- Dagosta FCP, de Pinna M. Biogeography of Amazonian fishes: deconstructing river basins as biogeographic units. Neotrop Ichthyol. 2017; 15(3):e170034. https://doi. org/10.1590/1982-0224-20170034

- Dagosta FCP, de Pinna M. The fishes of the Amazon: distribution and biogeographical patterns, with a comprehensive list of species. Bull Amer Mus Nat Hist. 2019; (431):1-163. https://doi. org/10.1206/0003-0090.431.1.1
- Deprá GC, Azevedo-Santos VM, Vitorino Júnior OB, Dagosta FCP, Marinho MMF, Benine RC. Moenkhausia goya (Characiformes: Characidae): a new species from the upper rio Tocantins basin, central Brazil. Zootaxa. 2018a; 4514(1):87-96. https://doi.org/10.11646/ zootaxa.4514.1.7

- Deprá GC, Graça WJ, Pavanelli CS, Avelino GS, Oliveira C. Molecular phylogeny of Planaltina Böhlke (Characidae: Stevardiinae) and comments on the definition and geographic distribution of the genus, with description of a new species. PLoS ONE. 2018b; 13(5):e0196291. https://doi.org/10.1371/ journal.pone.0196291

- Eigenmann CH. The American Characidae (Part 2). Mem Mus Comp Zool. 1918; 43:103-208.

- Eigenmann $\mathbf{C H}$. The American Characidae (Part 4). Mem Mus Comp Zool. 1927; 43:311-428.

- Eigenmann CH, Myers GS. The American Characidae (Part 5). Mem Mus Comp Zool. 1929; 43:429-558. 
- Esguícero ALH, Castro RMC. Knodus figueiredoi, a new characid from the rio das Garças, upper rio Araguaia basin, Brazil, with comments on the taxonomic limits of the genera Knodus and Bryconamericus (Teleostei: Characidae). Ichthyol Explor Freshw. 2014; 25(1):39-48.

- Ferreira KM. Análise filogenética e revisão taxonômica do gênero Knodus Eigenmann, 1911 (Characiformes: Characidae). [PhD Thesis]. Ribeirão Preto: Universidade de São Paulo; 2007.

- Ferreira KM, Carvajal FM. Knodus shinahota (Characiformes: Characidae) a new species from the río Shinahota, río Chapare basin (Mamoré system), Bolivia. Neotrop Ichthyol. 2007; 5(1):3136. http://dx.doi.org/10.1590/S167962252007000100004

- Ferreira KM, Lima FCT. A new species of Knodus (Characiformes: Characidae) from the rio Tiquié, Upper rio Negro system, Brazil. Copeia. 2006; 2006(4):63039. https://doi.org/10.1643/00458511(2006)6[630:ANSOKC]2.0.CO;2

- Ferreira KM, Netto-Ferreira AL. Knodus dorsomaculatus (Characiformes: Characidae), a new species from Teles Pires River, Tapajós River basin, Brazil. J Fish Biol. 2010; 7(3)7:468-78. https://doi. org/10.1111/j.1095-8649.2010.02680.x

- Fink WL, Weitzman SH. The so-called cheirodontin fishes of Central America with descriptions of two new species (Pisces: Characidae). Smithson Contrib Zool. 1974; (172):1-46.

- Fricke R, Eschmeyer WN, Van der Laan R, editors. Eschmeyer's Catalog of fishes: genera, species, references [Internet]. San Francisco: California Academy of Science; 2020. Available from: http:// researcharchive.calacademy.org/research/ ichthyology/catalog/fishcatmain.asp

- García-Melo JE, Albornoz-Garzón JG, García-Melo LJ, Villa-Navarro FA, Maldonado-Ocampo JA. A new species of Hemibrycon (Characiformes, Characidae, Stevardiinae) from the upper Magdalena River basin in Colombia. J Fish Biol. 2018; 92(6):1929-55. https://doi.org/10.1111/ jfb.13634
- García-Melo JE, Oliveira C, Costa Silva GJ, Ochoa-Orrego LE, Pereira LHG, Maldonado-Ocampo JA. Species delimitation of neotropical characins (Stevardiinae): Implications for taxonomy of complex groups. PLoS ONE. 2019; 14(6):e0216786. https://doi.org/10.1371/ journal.pone.0216786

- Géry J. Characoids of the world. Neptune City: TFH Publications; 1977.

- Higuchi H. An updated list of Ichthyological collecting stations of the Thayer Expedition to Brazil (1865-1866). Cambridge (USA): Museum of Comparative Zoology, Harvard University; 2016. Available from: https://hwpi.harvard. edu/files/mcz/files/higuchi_1996_thayer_ formated_prelim.pdf

- Hildebrand SF, Schroeder WC. Fishes of Chesapeake Bay. Bureau Fisheries \& U.S. Department of Commerce; Bulletin vol. XLIII - Part 1. The Balck Press; 1928.

- Isbrücker IJH. Status of the primary homonymous South American catfish Loricaria cirrhosa Perugia, 1897, with remarks on some other loricariids (Pisces, Siluriformes, Loricariidae). Ann Mus Civ. Stor Nat Giacomo Doria. 1973; 79:172-91.

- Landim MI, Moreira CR, Figueiredo CA. Retroculus acherontos, a new species of cichlid fish (Teleostei) from the rio Tocantins basin. Zootaxa. 2015; 3973(2):369-80. http://dx.doi.org/10.11646/ zootaxa.3973.2.10

- Lima FCT, Britski HA, Machado FA. New Knodus (Ostariophysi: Characiformes: Characidae) from the upper rio Paraguay basin, Brazil. Copeia. 2004; 2004(3):577-82. http://dx.doi.org/10.1643/CI-03-297R1

- Lima FCT, Malabarba LR, Buckup PA, Silva JFP, Vari RP, Harold A, Benine R, Oyakawa OT, Pavanelli CS, Menezes NA, Lucena CAS, Malabarba MCSL, Lucena ZMS, Reis RE, Langeani F, Cassati L, Bertaco VA, Moreira C, Lucinda PHF. Genera Incertae Sedis in Characidae. In: Reis RE, Kullander SO, Ferraris CJ, Jr., editors. Check list of the freshwater fishes of South and Central America. Porto Alegre: Edipucrs; 2003. p.106-69.

- Menezes NA, Ferreira KM, NettoFerreira AL. A new species of Knodus (Characiformes: Characidae: Stevardiinae) from the rio Aripuanã, rio Madeira basin, Brazil. Neotrop Ichthyol. 2020; 18(2):e190139. https://doi. org/10.1590/1982-0224-2019-0139 
- Menezes NA, Marinho MMF. A new species of Knodus Eigenmann (Characiformes: Characidae: Stevardiinae) with comments on nuptial tubercles and gill gland in characiform fishes. PLoS ONE. 2019; 14(7):e0217915 https://doi. org/10.1371/journal.pone.0217915

- Menezes NA, Netto-Ferreira AL, Ferreira KM. A new species of Bryconadenos (Characiformes: Characidae) from the rio Curuá, rio Xingu drainage, Brazil. Neotrop Ichthyol. 2009; 7(2):147-52. https://doi.org/10.1590/S167962252009000200003

- Mirande JM. Phylogeny of the family Characidae (Teleostei: Characiformes): from characters to taxonomy. Neotrop Ichthyol. 2010; 8(3):385-568. https://doi. org/10.1590/S1679-62252010000300001

- Mirande JM. Morphology, molecules and the phylogeny of Characidae (Teleostei, Characiformes). Cladistics. 2019; 35(3):282-300. https://doi.org/10.1111/ cla. 12345

- Ribeiro MCLB, Petrere Júnior M, Juras AA. Ecological integrity and fisheries ecology of the Araguaia-Tocantins river basin, Brazil. Regul Rivers: Res Manage. 1995; 11(3-4):325-50. https://doi. org/10.1002/rrr.3450110308

- Román-Valencia C, Taphorn DC, Ruiz-C RI. Two new Bryconamericus: $B$. cinarucoense $\mathrm{n}$. $\mathrm{sp}$. and B. singularis $\mathrm{n}$. sp. (Characiformes, Characidae) from the Cinaruco River, Orinoco basin, with keys to all Venezuelan species. Animal Biodivers Conserv. 2008; 31(1):15-27.

- Sabaj MH. Codes for natural history collections in ichthyology and herpetology. Copeia. 2020; 108(3):593-669. https://doi. org/10.1643/ASIHCODONS2020

- Soares IM, Bertaco VA, Ito PM, Zuanon J. A new species of Boehlkea (Characiformes: Characidae: Stevardiinae) from the rio Japurá, Amazon basin, Brazil. Neotrop Ichthyol. 2017; 15(3):e170026. https://doi. org/10.1590/1982-0224-20170026

- Sousa DJA, Silva-Oliveira C, Canto ALC, Ribeiro FRV. A new species of Knodus (Characiformes: Characidae) from the rio Cupari drainage, lower rio Tapajós basin, Brazil. Zootaxa. 2020; 4747(3):575-84. https://doi.org/10.11646/zootaxa.4747.3.10
- Taylor WR, Van Dyke GC. Revised procedures for clearing and staining small fishes and other vertebrates for bone and cartilage study. Cybium. 1985; 9(2):107-20.

- Thomaz AT, Arcila D, Ortí G, Malabarba LR. Molecular phylogeny of the subfamily Stevardiinae Gill, 1858 (Characiformes: Characidae): Classification and the evolution of reproductive traits. BMC Evol Biol. 2015; 15(1):146. https://doi. org/10.1186/s12862-015-0403-4

- Weitzman SH. The osteology of Brycon meeki, a generalized characid fish, with an osteological definition of the family. Stanford Ichthyol Bull. 1962; 8(1):1-77.

- Weitzman SH, Menezes NA, Evers H-G, Burns JR. Putative relationships among inseminating and externally fertilizing characids, with a description of a new genus and species of Brazilian inseminating fish bearing an analfin gland in males (Characiformes: Characidae). Neotrop Ichthyol. 2005; 3(3):329-60. https://doi.org/10.1590/S167962252005000300002

- Winemiller KO. Patterns of variation in life history among South American fishes in seasonal environments. Oecologia. 1989; 81(2):225-41. https://doi.org/10.1007/ bf00379810

- Zarske A. Knodus pasco sp. n. - ein nuer Salmler (Teleostei: Characiformes: Characidae) aus Peru. Vertebr Zool. 2007; 57(1):15-21.

- Zarske A. Knodus borki sp. n. - ein neuer Salmler aus Peru mit einer ergänzenden Beschreibung von Boehlkea fredcochui Géry, 1966 (Teleostei: Characiformes: Characidae). Vertebr Zool. 2008; 58(2):15971.

- Zarske A, Géry J. Knodus longus sp. n. - ein nuer Salmler (Teleostei: Characiformes: Characidae) aus den bolivianischen Anden, Einzungsgebiet des río Beni. Zool Abh. 2006; 55:51-57. 


\section{Neotropical Ichthyology}

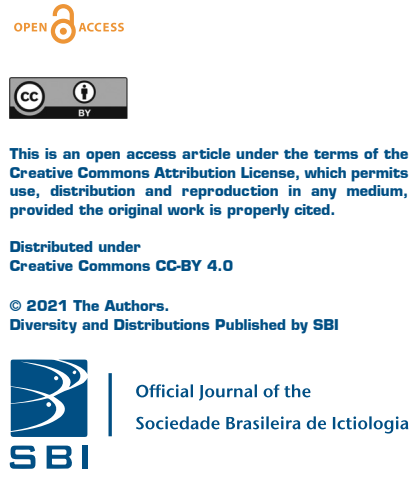

\section{AUTHOR'S CONTRIBUTION 중}

Gabriel de Carvalho Deprá: Conceptualization, Data curation, Formal analysis, Investigation, Methodology, Writing-original draft, Writing-review and editing.

Renata Rúbia Ota: Data curation, Formal analysis, Investigation, Writing-original draft, Writing-review and editing.

Oscar Barroso Vitorino Júnior: Conceptualization, Investigation, Project administration, Resources,

Writing-original draft, Writing-review and editing.

Katiane Mara Ferreira: Data curation, Formal analysis, Investigation, Methodology, Supervision, Writingoriginal draft, Writing-review and editing.

\section{ETHICAL STATEMENT}

The research was carried out under the license number SISBIO 53599-1, CEUA- 6052270716, from the Animal Ethics Committee of the Universidade Estadual de Maringá (UEM).

\section{COMPETING INTERESTS}

The authors declare no competing interests.

\section{HOW TO CITE THIS ARTICLE}

- Deprá GC, Ota RR, Vitorino Júnior OB, Ferreira KM. Two new species of Knodus (Characidae: Stevardiinae) from the upper rio Tocantins basin, with evidence of ontogenetic meristic changes. Neotrop Ichthyol. 2021; 19(1):e200106. https://doi.org/10.1590/1982-02242020-0106 